\title{
Concentrations and fluxes of aerosol particles during the LAPBIAT measurement campaign at Värriö field station
}

\author{
T. M. Ruuskanen ${ }^{1}$, M. Kaasik ${ }^{2}$, P. P. Aalto ${ }^{1}$, U. Hõrrak ${ }^{7}$, M. Vana ${ }^{1,7}$, M. Mårtensson ${ }^{3}$, Y. J. Yoon ${ }^{4}$, P. Keronen ${ }^{1}$, \\ G. Mordas $^{1}$, D. Ceburnis ${ }^{4}$, E. D. Nilsson ${ }^{3}$, C. O'Dowd ${ }^{4}$, M. Noppel ${ }^{7}$, T. Alliksaar ${ }^{5}$, J. Ivask ${ }^{5}$, M. Sofiev ${ }^{6}$, M. Prank ${ }^{2}$, \\ and M. Kulmala ${ }^{1}$ \\ ${ }^{1}$ University of Helsinki, Dept. of Physical Sciences, P.O. Box 64, 00014 University of Helsinki, Finland \\ ${ }^{2}$ Institute of Environmental Physics, University of Tartu, Tartu, Estonia \\ ${ }^{3}$ Department of Applied Environmental Science, Stockholm University, Stockholm, Sweden \\ ${ }^{4}$ Department of Experimental Physics, National University of Ireland, Galway, Ireland \\ ${ }^{5}$ Institute of Geology, Tallinn University of Technology, Tallinn, Estonia \\ ${ }^{6}$ Air Quality Research, Finnish Meteorological Institute, Finland \\ ${ }^{7}$ Institute of Physics, University of Tartu, Tartu, Estonia
}

Received: 21 November 2006 - Published in Atmos. Chem. Phys. Discuss.: 17 January 2007

Revised: 25 April 2007 - Accepted: 3 June 2007 - Published: 16 July 2007

\begin{abstract}
The LAPBIAT measurement campaign took place in the Värriö SMEAR I measurement station located in Eastern Lapland in the spring of 2003 between 26 April and 11 May. In this paper we describe the measurement campaign, concentrations and fluxes of aerosol particles, air ions and trace gases, paying special attention to an aerosol particle formation event broken by a air mass change from a clean Arctic air mass with new particle formation to polluted one approaching from industrial areas of Kola Peninsula, Russia, lacking new particle formation. Aerosol particle number flux measurements show strong downward fluxes during that time. Concentrations of coarse aerosol particles were high for 1-2 days before the nucleation event (i.e. 28-29 April), very low immediately before and during the observed aerosol particle formation event (30 April) and increased moderately from the moment of sudden break of the event. In general particle deposition measurements based on snow samples show the same changes. Measurements of the mobility distribution of air ions showed elevated concentrations of intermediate air ions during the particle formation event. We estimated the growth rates in the nucleation mode size range. For particles $<10 \mathrm{~nm}$, the growth rate increases with size on 30 April. Dispersion modelling made with model SILAM support the conclusion that the nucleation event was interrupted by an outbreak of sulphate-rich air mass in the evening of 30 April that originated from the industry at Kola Peninsula,
\end{abstract}

Correspondence to: T. M. Ruuskanen

(taina.ruuskanen@helsinki.fi)
Russia. The results of this campaign highlight the need for detailed research in atmospheric transport of air constituents for understanding the aerosol dynamics.

\section{Introduction}

Atmospheric aerosols have a large impact on the radiative balance and climate both directly, by scattering sun light back to space, and indirectly, by acting as cloud condensation nuclei $(\mathrm{CCN})$ and changing the albedo and life time of clouds (Charlson and Wigley, 1994). Estimating the impact of aerosols on climate is especially difficult since the effect of aerosol depends on properties e.g. concentration, size and composition of aerosols and aerosol properties vary significantly in space and time. New aerosol particle formation has been observed in different types of environments in the free troposphere (Clarke, 1992; Schröder and Ström, 1997), in the marine boundary layer (O'Dowd, 2002a), in Arctic areas (Pirjola et al., 1998), in urban areas (Kerminen and Wexler, 1996), in boreal forest (Mäkelä et al., 1997; Tunved et al., 2003) and in relation to air ion formation events (Vana et al., 2004). A recent overview (Kulmala et al., 2004a) summarise observations.

Formation of new aerosol particles is observed $60-120$ times a year in southern (Kulmala et al., 2001; Dal Maso et al., 2005) and 25-60 times in northern Finland (Komppula et al., 2003, 2006; Vehkamäki et al., 2004). It has been

Published by Copernicus Publications on behalf of the European Geosciences Union. 
suggested that formation and growth are two separate processes and involve different gas phase species taking part in them. Formation of new aerosol particles has been suggested to result from binary nucleation of $\mathrm{H}_{2} \mathrm{SO}_{4}$ and $\mathrm{H}_{2} \mathrm{O}$ (Kulmala et al., 1998) or ternary nucleation of $\mathrm{H}_{2} \mathrm{SO}_{4}, \mathrm{NH}_{3}$ and $\mathrm{H}_{2} \mathrm{O}$ (Korhonen et al., 1999). Modelling and experimental results show that ion-induced nucleation can also be considered as a possible mechanism for particle generation (Laakso et al., 2004a, b). In many cases, sulphuric acid plays a role in new particle formation (Kulmala et al., 2006a). However, in some special cases, such as in deep convective clouds, atmospheric nucleation can occur without sulphuric acid (Kulmala et al., 2006b). Kulmala et al. (2000) suggested that nucleation occurs almost everywhere in the atmosphere during daytime but, as it results in aerosol particles smaller than the detectable size, we cannot observe it without subsequent growth. Growth of newly formed aerosol particles in boreal forest has been suggested to be due to heterogeneous nucleation and condensation from the emitted biogenic volatile organic compounds (BVOC's) or their oxidation products. Boreal forests are one possible source of BVOC's that can be oxidized to less volatile species. For example terpenoids are emitted from coniferous forests, especially in the spring and summer (Hakola et al., 2003). In the Northern Hemisphere solar radiation is high in spring and there is a spring time maximum in the ozone concentration in unpolluted northern areas (Logan et al., 1985) that is also observed in Finnish Lapland (Ruuskanen et al., 2003) leading to effectively oxidizing conditions. Oxidation products of several terpenoids have been identified from aerosols, of e.g. isoprene (Clayes et al., 2004, Kourtchev et al., 2005), monoterpenes (O'Dowd et al., 2002), and sesquiterpenes (Bonn and Mootgard, 2003). O'Dowd et al. (2002b) state that compounds, such as cispinonic acid and pinic acid, that are oxidation products of monoterpenes, participate in the growth of new aerosol particles.

A lot of research has focused on characterising the aerosol particle formation events and the parameters that control observed new aerosol particle formation (Kulmala et al., 1998; Mäkelä et al., 2000; Buzorius et al., 2001; Boy et al., 2002). Several field studies have concentrated on observations of the formation and growth of newly formed aerosol particles in Southern Finland (Kulmala et al., 2001). Also involvement of air ions in new aerosol particle events has been studied (Laakso et al., 2004b). The understanding of aerosol particle formation events has increased, but the processes involved are still not fully understood. Chemical conditions are more confined in Northern Finland. There are less anthropogenic sources and these are easy to identify, the contribution from local diffuse background sources is negligible and often welldefined plumes are formed. In fact, three different influencing source areas can be defined for Finnish Lapland: Kola Peninsula, continental Europe and marine. The effect can be seen in trace gas concentrations as well as aerosol number concentration (Ruuskanen et al., 2003) and scattering coeffi- cient (Virkkula et al., 1997). Also a recent modelling study (Komppula et al., 2006) has focussed on those effects.

LAPBIAT (Lapland Atmosphere-Biosphere facility) measurement campaign took place in the Värriö SMEAR I measurement station located in Eastern Lapland in the spring of 2003 between 26 April and 11 May. LAPBIAT is an EU programs and its goal is to enhance the international scientific co-operation at the Finnish Arctic research stations involved in the program. During this LAPBIAT campaign the variation of the concentration of aged aerosols of anthropogenic origin as well as formation and growth of aerosol particles in sub-arctic boreal area was studied with versatile aerosol particle and air ion size distribution measurements supported by deposition studies based on aerosol fluxes and snow chemistry. Trace gases $\left(\mathrm{SO}_{2}\right.$ and $\left.\mathrm{O}_{3}\right)$, aerosol particle concentration and meteorological parameters were continuously measured since 1992 in SMEAR I-station (Station for Measuring Forest Ecosystem - Atmosphere Relation) located in Northern Lapland. Several other measurements like $\mathrm{NO}_{\mathrm{x}}$ and aerosol size distribution, to name a few, were started later. The aim of this work is to study closely two weeks during spring, when the aerosol particle formation events occur most frequently and to look at a specific aerosol particle formation event, which was interrupted by a pollution event, in detail.

\section{Experimental}

\subsection{Location}

The SMEAR I (Station for Measuring Forest Ecosystem Atmosphere Relation) station $\left(67^{\circ} 46^{\prime} \mathrm{N}, 29^{\circ} 35^{\prime} \mathrm{E}\right)$ (Hari et al., 1994) is located in Värriö nature park in eastern Lapland, less than ten kilometres from the border of Russia. The measurements were made from different heights of a measurement tower located on top of a hill $390 \mathrm{~m}$ above sea level (a.s.l.). The station is located below the alpine timberline ( $400 \mathrm{~m}$ a.s.l.) but it is surrounded by the range of Värriö fjelds above the timberline that continue from north to south. Most of the trees in the surrounding areas are about 50-years-old Scots pines (Pinus Sylvestris L.) and the height of the trees is about eight metres and the mean diameter approximately eight centimetres. The distance from the nearest small road to the station is approximately eight kilometres and from the nearest major road about $100 \mathrm{~km}$. There are no towns or industry close by. Having practically no local pollution gives an opportunity to observe background concentrations and mid- to long-range transport of long-lived pollutants. The nearest major pollution sources are metallurgy factories of Montchegorsk located $150 \mathrm{~km}$ east and Nikel located $190 \mathrm{~km}$ north from the station. Since anthropogenic emissions come from well-defined sources and often in well-defined plumes, namely from Kola Peninsula, we have a great opportunity to study aerosol formation events, 
Table 1. The list of continuous measurements in SMEAR I station, during LAPBIAT campaign.

\begin{tabular}{|c|c|c|c|}
\hline Quantity & Measurement height & Instrument/method & Brand \\
\hline temperature & $15,9,6.6,4.4,2.2 \mathrm{~m}$ & Pt-100 sensors & shielded and ventilated \\
\hline wind speed & $15,9,6.6,2.2 \mathrm{~m}$ & cup anemometer & $\begin{array}{l}\text { Vector Instruments } \\
\text { A } 101 \mathrm{M} / \mathrm{L}\end{array}$ \\
\hline wind direction & $15 \mathrm{~m}$ & wind vane & Vector Instruments W 200 P \\
\hline RH & $2 \mathrm{~m}$ & dew point & Vaisala HMI32 Humicap \\
\hline air pressure & $2 \mathrm{~m}$ & barometer & Druck DPI 260 \\
\hline rain fall & $1 \mathrm{~m}$ & rain gauge & Delta-T RG1 \\
\hline rain detection & $15 \mathrm{~m}$ & precipitation sensor & Vaisala DPD 12A \\
\hline UV-A & $15 \mathrm{~m}$ & pyranometer & Solar Light SL 501A \\
\hline UV-B & $15 \mathrm{~m}$ & pyranometer & Solar Light SL 501A \\
\hline $\begin{array}{l}\text { PAR } \\
\text { (range } 400-700 \mathrm{~nm})\end{array}$ & $15 \mathrm{~m}$ & quantum sensor & Li-Cor LI-190SB \\
\hline $\begin{array}{l}\text { Global } \\
(\text { range } 300-4800 \mathrm{~nm})\end{array}$ & $15 \mathrm{~m}$ & pyranometer & Astrodata, Reemann TP 3 \\
\hline $\mathrm{NO}_{\mathrm{X}}$ & $15,9,6.6,2.2 \mathrm{~m}$ & $\begin{array}{l}\text { chemiluminescence, } \\
\text { Molybdenum } \mathrm{NO}_{2} \text {-to-NO } \\
\text { converter }\end{array}$ & $\begin{array}{l}\text { Thermo Environmental Instru- } \\
\text { ments } 42 \mathrm{CTL}\end{array}$ \\
\hline $\mathrm{O}_{3}$ & $15,9,6.6,2,2 \mathrm{~m}$ & UV light absorption & $\begin{array}{l}\text { Advanced Pollution Instrumenta- } \\
\text { tion API } 400\end{array}$ \\
\hline $\mathrm{SO}_{2}$ & $15,9,6.6,2.2 \mathrm{~m}$ & fluorescence & $\begin{array}{l}\text { Thermo Environmental Instru- } \\
\text { ments 43CTL }\end{array}$ \\
\hline $\begin{array}{l}\text { aerosol particle concentra- } \\
\text { tion } \\
(14 \mathrm{~nm}-1 \mu \mathrm{m})\end{array}$ & $15,9,6.6,2.2 \mathrm{~m}$ & $\begin{array}{l}\text { condensation particle } \\
\text { counter (CPC) }\end{array}$ & $\begin{array}{l}\text { TSI 3760, detection limit } \\
10^{-3} \text { particles } \mathrm{cm}^{-3}\end{array}$ \\
\hline $\begin{array}{l}\text { aerosol particle size distri- } \\
\text { bution }(10 \mathrm{~nm}-500 \mathrm{~nm})\end{array}$ & $2 \mathrm{~m}$ & electrical mobility & $\begin{array}{l}\text { Differential Mobility Particle } \\
\text { Sizer (DMPS) and CPC, TSI } \\
3010\end{array}$ \\
\hline
\end{tabular}

aerosol and air ion dynamics and atmospheric chemistry in clean and polluted air masses.

\subsection{Physical and chemical measurements from air}

The continuous trace gas $\left(\mathrm{SO}_{2}, \mathrm{NO}_{\mathrm{x}}, \mathrm{O}_{3}\right)$, aerosol particle size distribution (DMPS, $8 \mathrm{~nm}-0.45 \mu \mathrm{m})$ and number concentration of aerosol particles (CPC, $14 \mathrm{~nm}-3 \mu \mathrm{m})$ alongside with meteorological measurements are described in more detail by Ruuskanen et al. (2003) and Hari et al. (1994). Details of continuous measurements are shown in Table 1. More detail aerosol measurements were made during the measurement campaign. Positive and negative air ions were measured with an Air Ion Spectrometer (AIS) from size range of $0.46 \mathrm{~nm}$ to $41 \mathrm{~nm}$. Aerosol particles were also measured with an Aerodynamic Particle Sizer (APS), Electrical Aerosol Spectrometer (EAS), a Pulse Height Analyser con- nected to a CPC (PHAUCPC) (Marti et al., 1996; O'Dowd et al., 2005) and different CPCs (e.g. LICPCs) (Mordas et al., 2005). Campaign measurements are summed up in Table 2. Backward trajectories $(96 \mathrm{~h}$ ) were calculated using FNL data on the HYSPLIT4 model (Draxler and Rolph, 2003) for the levels of 500, 1200 and $2000 \mathrm{~m}$.

Size segregated aerosol mass and inorganic composition was measured using a Micro-Orifice Uniform Deposit Impactor (MOUDI). The MOUDI uses circular jets to separate particles aerodynamically onto ten impaction stages plus an inlet stage within a range of $0.056-18 \mu \mathrm{m}$ (flow rate $1.8 \mathrm{~m}^{3} \mathrm{~h}^{-1}$, equivalent aerodynamic cut-off diameters at $50 \%$ efficiency: $0.056 ; 0.10 ; 0.18 ; 0.32 ; 0.56 ; 1.0 ; 1.8 ; 3.2 ; 5.6$; $10 ; 18 \mu \mathrm{m})$. The instrument was located in ambient environment with only inlet protected from rain. The inlet of the MOUDI was about $1 \mathrm{~m}$ above ground. The MOUDI sample was approximately one week long in order to collect 
Table 2. The list of instruments used in measurements during the LAPBIAT measurement campaign at SMEAR I station.

\begin{tabular}{|c|c|c|}
\hline Measured quantity & Used method/Instrument & Operated by \\
\hline $\begin{array}{l}\text { Positive and negative aerosol ion particle } \\
\text { size distribution, } 0.46 \mathrm{~nm}-41 \mathrm{~nm}\end{array}$ & Aerosol Ion Spectrometer, AIS & University of Tartu \\
\hline Aerosol size distribution, $3.2 \mathrm{~nm}-10 \mu \mathrm{m}$ & Electrical Aerosol Spectrometer, EAS & University of Tartu \\
\hline $\begin{array}{l}\text { Aerosol size distribution, } \\
0.5 \mu \mathrm{m}-20 \mu \mathrm{m}\end{array}$ & Aerodynamic Particle Sizer, APS 3320 & National University of Ireland, Galway \\
\hline $\begin{array}{l}\text { Ultrafine aerosol size distribution, } 3 \mathrm{~nm}- \\
25 \mathrm{~nm}\end{array}$ & $\begin{array}{l}\text { UF-DMPS, } 10.9 \mathrm{~cm} \text { long Hauke type } \\
\text { DMA and TSI } 3025 \mathrm{CPC}\end{array}$ & University of Helsinki \\
\hline $\begin{array}{l}\text { Ultrafine aerosol concentration, 2.7- } \\
5 \pm 1 \mathrm{~nm}\end{array}$ & $\begin{array}{l}\text { Pulse Height Analyzer with Ultrafine } \\
\text { Condensation Particle Counter, PHA- } \\
\text { UCPC }\end{array}$ & National University of Ireland, Galway \\
\hline $\begin{array}{l}\text { Aerosol number concentration }(>4.5 \mathrm{~nm} \text {, } \\
>10 \mathrm{~nm})\end{array}$ & Prototype of Lithuanian CPC & $\begin{array}{l}\text { University of Helsinki, Lithuanian Institute of } \\
\text { Physics }\end{array}$ \\
\hline Aerosol number flux (>11 nm) & Eddy Covariance with TSI 3762 CPC & University of Stockholm \\
\hline $\begin{array}{l}\text { Aerosol (spheroidal ash particles) depo- } \\
\text { sition to snow cover }\end{array}$ & $\begin{array}{l}\text { Stereomicroscope, } 125 \mathrm{x} \text { magnification, } \\
\text { snow samples }\end{array}$ & Tallinn University of Technology \\
\hline $\begin{array}{l}\text { Size-segregated aerosol mass } \\
\text { and inorganic composition, } \\
0.056-18.0 \mu \mathrm{m}\end{array}$ & $\begin{array}{l}\text { MOUDI (micro-orifice uniform deposit } \\
\text { impactor), } 12 \text { stage }\end{array}$ & National University of Ireland, Galway \\
\hline Deposition of ions to snow cover & Ion chromatography, snow samples & Tallinn University of Technology \\
\hline
\end{tabular}

sufficient particulate matter to make accurate gravimetric analysis, owing to low particulate mass in remote arctic atmosphere. The MOUDI impactor was mounted with Al foils, which were preconditioned for $24 \mathrm{~h}$ at $35-40 \%$ relative humidity and $20^{\circ} \mathrm{C}$ and weighed with a Mettler Toledo microbalance ( $1 \mu \mathrm{g}$ sensitivity). After sampling, the Al foils were conditioned again for $24 \mathrm{~h}$ and weighed. Fortnightly samples were obtained over the LAPBIAT campaign. As the accumulation and coarse modes were clearly revealed, no inversion technique was used to produce continuous spectra. Inorganic ions $\left(\mathrm{SO}_{4}^{2-}, \mathrm{NO}_{3}^{-}, \mathrm{NH}_{4}^{+}, \mathrm{Cl}^{-}, \mathrm{Na}^{+}, \mathrm{K}^{+}, \mathrm{Ca}^{2+}\right)$ were determined by ion chromatography (Dionex 2010i, negative ions), atomic emission spectrometry (positive ions) and indophenol-spectrometry for the determination of $\mathrm{NH}_{4}^{+}$. More details could be found in Sopauskiene and Jasineviciene (2006). Each impactor sample set included a blank Al foil, which was treated as a real sample including handling protocols. Blank values of chemical species were subtracted from samples.

\subsection{Eddy covariance flux measurements}

An eddy covariance (EC) flux measurement system from Stockholm University was operated in the SMEAR I measurement tower. The EC system consisted of an ultrasonic anemometer (Gill, model R3) and a CPC (TSI, model 3762) with a lower cut at $11 \mathrm{~nm}$ diameter. The CPC pulses were counted by a pulse counter, and logged over two analogue voltage channels on the ultrasonic anemometer interface at $20 \mathrm{~Hz}$ together with the vertical wind data. The vertical turbulent aerosol number flux $<\mathrm{N}^{\prime} \mathrm{w}$ ' $>$ was then calculated from the aerosol number $(\mathrm{N})$ and the vertical wind $(\mathrm{w})$. The experimental set up and the data treatment was identical to that followed by Mårtensson et al. (2006), except that we used an improved pulse-analogue converter and did not correct for the limited response time of the CPC. The experimental set up is similar to that used at SMEAR II station in Hyytiälä, Southern Finland (see e.g. Buzorius et al., 2001), except for a more modern anemometer version and a CPC model with larger sampling flow and hence smaller counting error. The aerosol was sampled through a $4.40 \mathrm{~m}$ long $1 / 4$ inch stainless steel tube at a flow of about $8 \mathrm{~L} \mathrm{~min}^{-1}$ (laminar) with the inlet just below the sonic head. The centre of the sonic head was at $16.40 \mathrm{~m}$ above the ground, which is to be considered the measurement height of the fluxes.

\subsection{Deposition measurements from snow samples}

Deposition measurements were based on the accumulation of chemical and particulate tracers in the natural snow layer. The first series of five samples (representing both forest and open land and hills and valleys) was taken in the morning and early afternoon of 27 April from the thin layer of fresh snow. The second series at same sites, plus one extra site, was taken in the morning of 1 May from the clearly distinguishable layer formed during the snowfall of 28-29 April. Thus, both washout and dry deposition during the snowfall up to the sampling time were caught in the same volume. One additional sample close to the SMEAR I station was taken at the afternoon of 29 April, i.e. in the end of the intense snowfall. 
The snow samples were melted in plastic bags and stored in plastic bottles for a few weeks until the analysis. Concentrations of anions and cations were measured using ion chromatography. Number concentrations of spheroidal flyash particles (larger than $5 \mu \mathrm{m}$ ) were determined using a light microscope. Spheroidal fly-ash particles are specific and chemically inert markers of high-temperature combustion of fossil fuels (Alliksaar et al., 1998), thus originating from anthropogenic sources: energy production, metal processing and other industrial processes consuming fuels. The snow samples were filtered and particles larger than $5 \mu \mathrm{m}$ were counted.

\section{Results}

\subsection{Local and synoptic weather}

The campaign took place during typical Lapland late winter weather: alternating sunny and cloudy days, frost during nights and temperatures above zero during days (Fig. 1). A few days before the beginning of campaign, 20-21 April, heavy thawing occurred, which left a $20-30 \mathrm{~cm}$ thick hard snow cover on the ground. The next days until 27 April were frosty with minimum of nearly $-10^{\circ} \mathrm{C}$ at night and maximum temperatures of some $0^{\circ} \mathrm{C}$ during midday. Winds at $10-1500 \mathrm{~m}$ heights blew permanently from Arctic Ocean, as seen from four day backward trajectories that were calculated using FNL data on the HYSPLIT4 model for several heights (not shown here). During this time, slight sporadic snowfalls formed a thin $(2-3 \mathrm{~cm})$ soft snow layer on the hard crust.

On 27-28 April a low pressure system passed over Northern Finland. The Arctic air masses started dipping into southern Finland and later down to St. Petersburg region before arriving at the SMEAR I station. At night of 28 April an intense snowfall begun and continued with short breaks until the evening of the next day.

After this last snowfall the daily temperatures got gradually warmer towards the end of the campaign, night minimum was $-3^{\circ} \mathrm{C}$ and day maximum $+9^{\circ} \mathrm{C}$ (Fig. 1). On 3 May the wind direction changed to westerly and the Arctic air toured over Scandinavia and on 7-10 May the air arrived again mainly from the Arctic.

\subsection{Conditions of the surface layer}

Observed upward sensible heat fluxes were highest at daytime of 30 April, about $200 \mathrm{~W} \mathrm{~m}^{-2}$ and more than $100 \mathrm{~W} \mathrm{~m}^{-2}$ at $3-5,8$ and 10 May. Night-time fluxes were downward, usually up to $50 \mathrm{~W} \mathrm{~m}^{-2}$, only a few shorttime fluctuations exceeded that value. The Monin-Obukhov length (Fig. 2) was under $-100 \mathrm{~m}$ or over $100 \mathrm{~m}$ most of time, thus near-surface stratification was slightly stable at night and slightly unstable at daytime. Remarkable exclusions were 30 April and 10 May, when the stratification changed from strongly stable to strongly unstable. Relatively strong
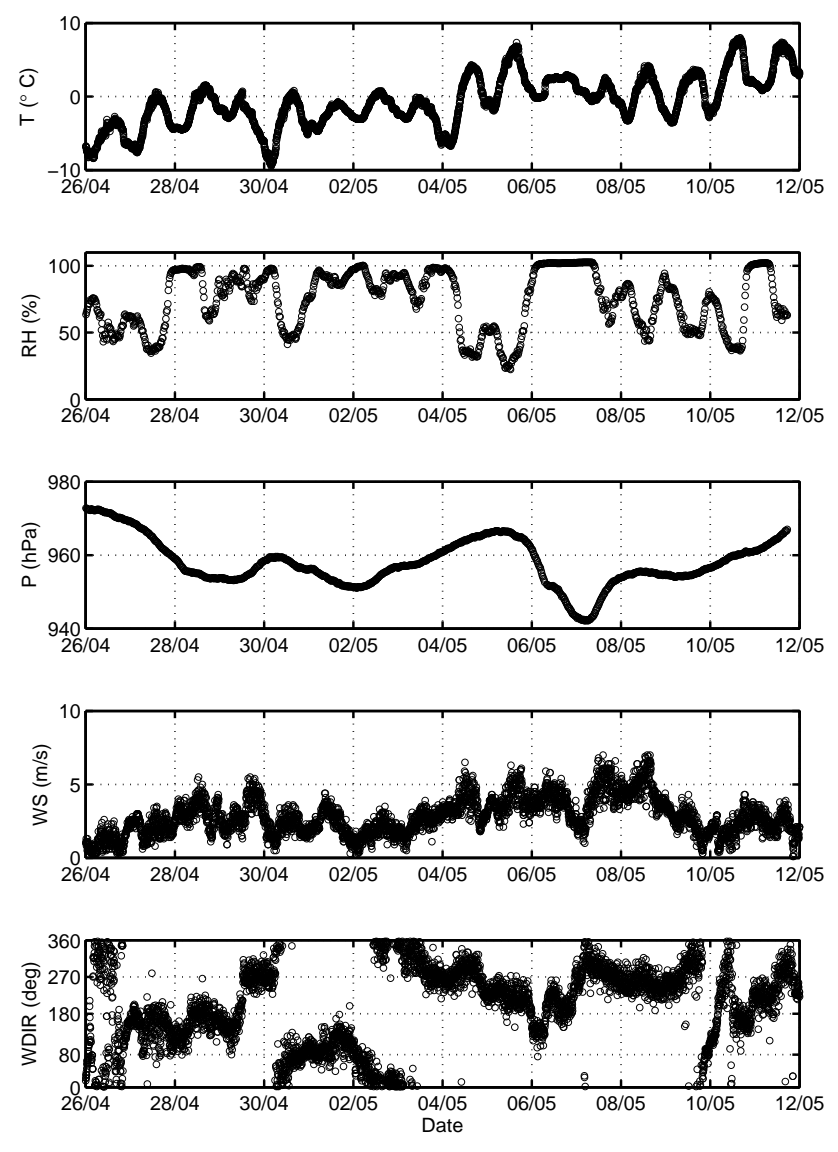

Fig. 1. Meteorological parameters measured at the SMEAR I station during the LAPBIAT measurement campaign.

instability occurred at daytime on 2 May and strong instability at night before 5 May.

\subsection{Trace gas and aerosol concentrations}

In general, concentrations of $\mathrm{SO}_{2}$ and $\mathrm{NO}_{\mathrm{x}}$, that are mainly of anthropogenic origin, were below detection limit and $0.5 \mathrm{ppb}$, respectively (Fig. 3). High concentrations, over $4 \mathrm{ppb}$ of $\mathrm{SO}_{2}$ and $2 \mathrm{ppb}$ of $\mathrm{NO}_{\mathrm{x}}$, were observed on 30 April and 1 May. Elevated $\mathrm{SO}_{2}$ and $\mathrm{NO}_{\mathrm{x}}$ concentration of some 1 ppb were observed around 28-29 April and 10 May. In addition $\mathrm{SO}_{2}$ concentration was 5-10 ppb on 3 May and $\mathrm{NO}_{\mathrm{x}}$ concentration was elevated up to $2 \mathrm{ppb}$ on 1 and 6 May. Ozone concentration was around $40 \mathrm{ppb}$, except on 29-30 April when it increased up to $60-50 \mathrm{ppb}$.

Concentrations of aerosol particles over $3 \mathrm{~nm}$ diameter ranged from minimum of a few hundred particles $\mathrm{cm}^{-3}$ before nucleation events to 10000 particles $\mathrm{cm}^{-3}$ during one of the three observed aerosol particle nucleation events (Fig. 3). In general, the aerosol particle concentrations were in the order of some thousands particles $\mathrm{cm}^{-3}$. The total aerosol particle concentrations of all used instruments followed each other, showing pretty consistent results even in the rapidly 


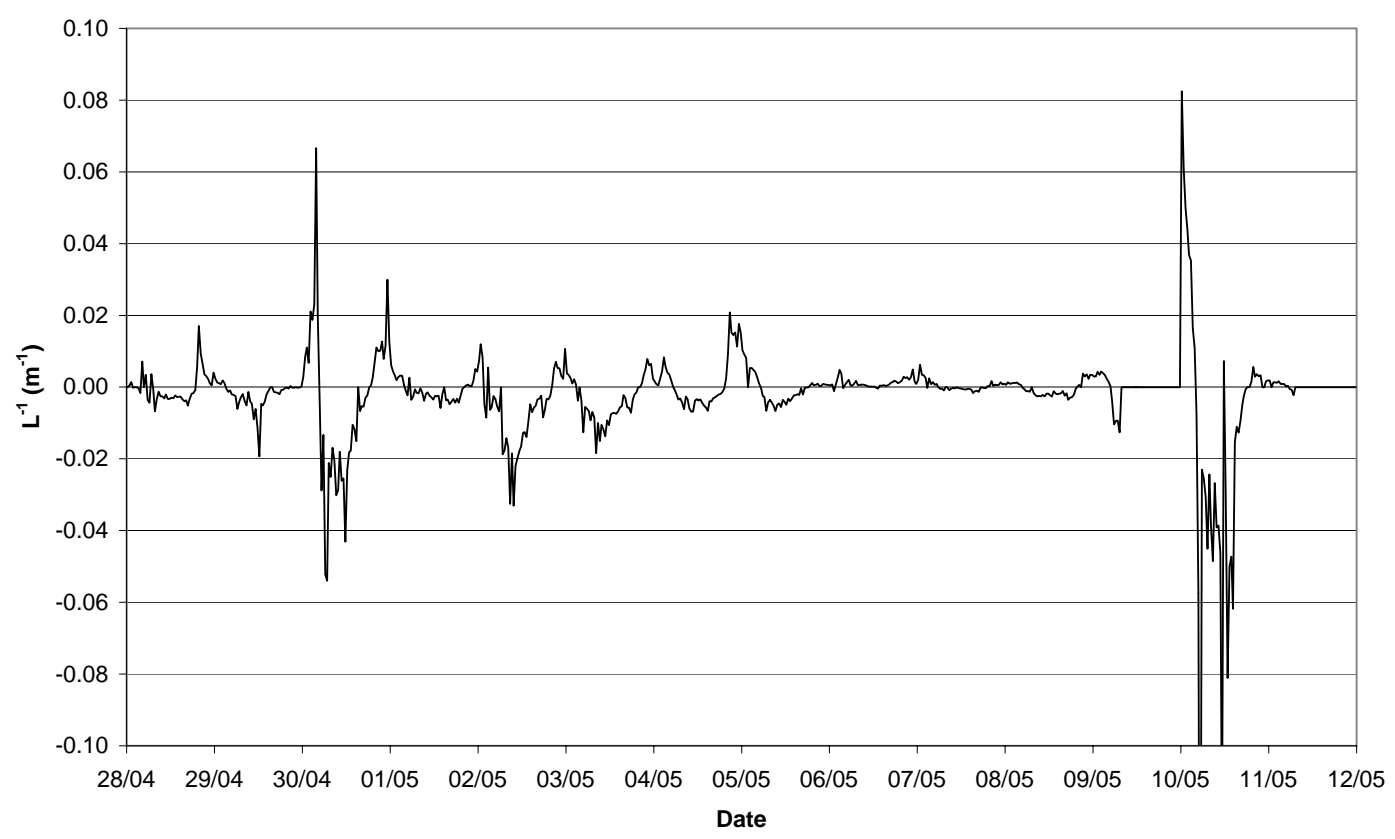

Fig. 2. Reverse value of Monin-Obukhov length at the SMEAR I station during the LAPBIAT measurement campaign.
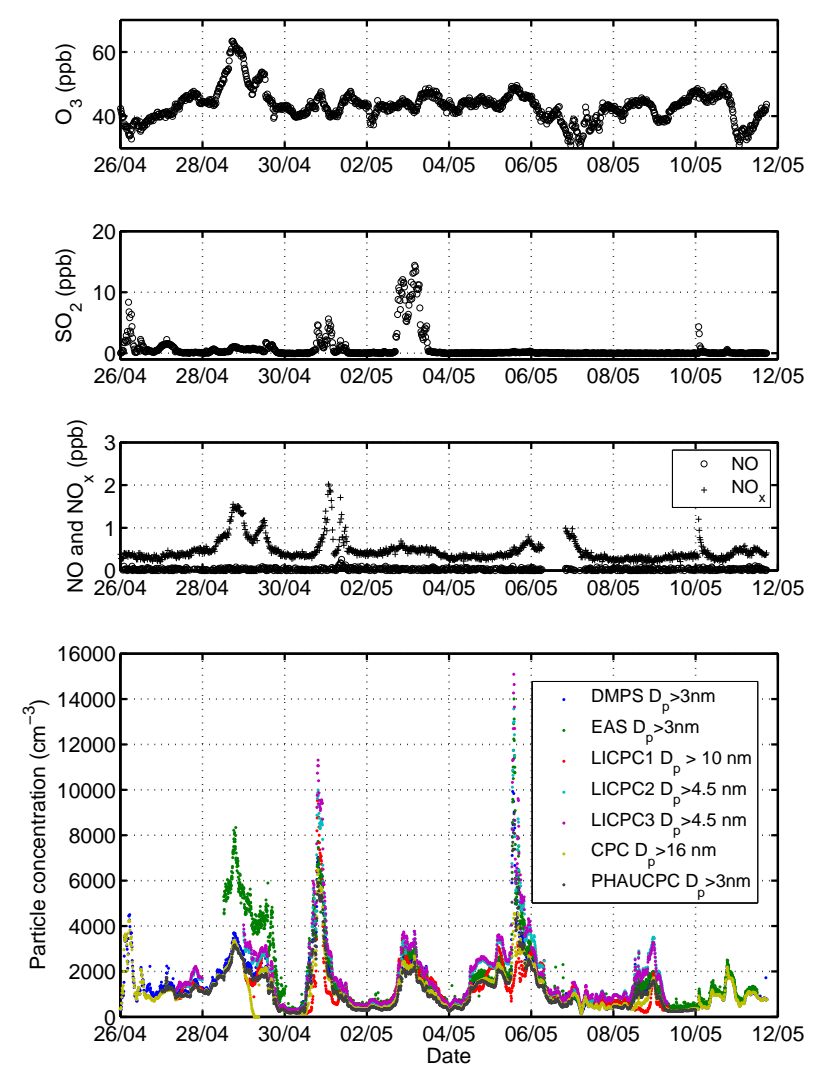

Fig. 3. Measured trace gas and aerosol number (for used aerosol measurement instruments see Table 2) concentrations at the SMEAR I station during the LAPBIAT measurement campaign.

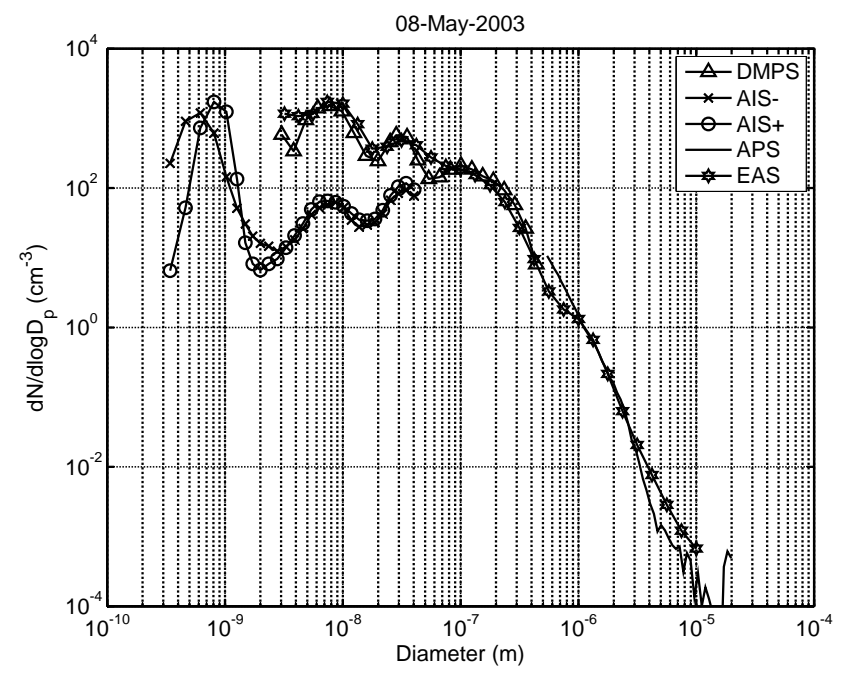

Fig. 4. Comparison of size distribution measurements performed using 4 different instruments at SMEAR I station. Air ion spectrometer measured only air ions all other measured total aerosol concentration.

changing meteorological conditions, e.g. in temperature and pressure, of Northern spring.

The aerosol particle and air ion size distributions measured using four different instruments are shown in Fig. 4. Also different size distribution measurements agreed with each other at overlapping sizes. APS was calibrated using MOUDI impactor as part of the campaign objectives. A comparison exercise revealed that APS was undercounting in submicron 

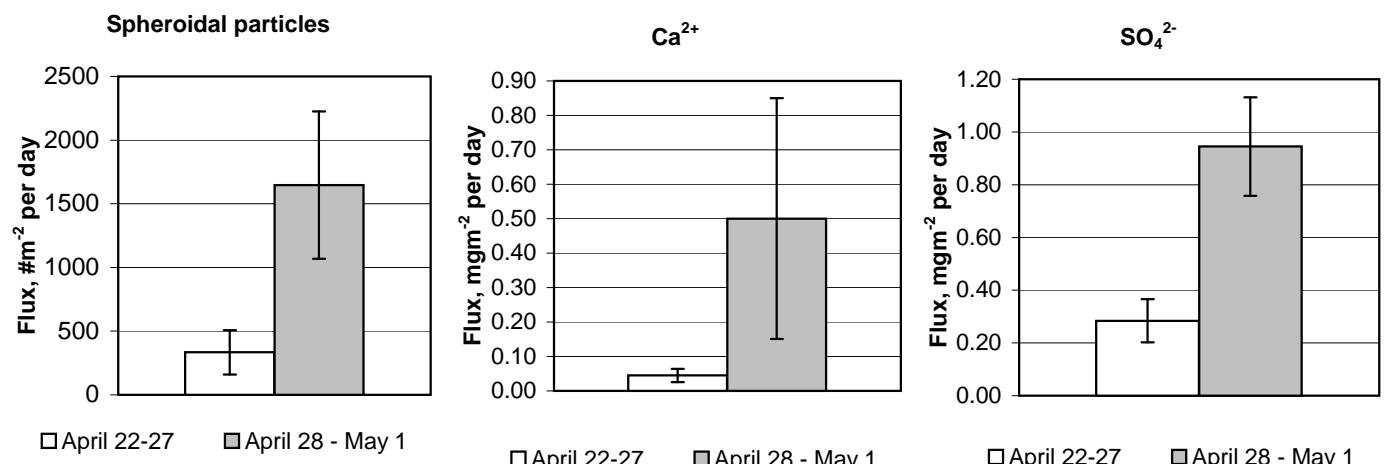

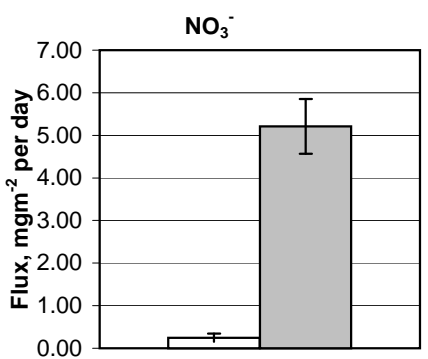

$\square$ April 22-27 $\square$ April 28 - May 1 $\square$ April 22-27 $\square$ April 28 - May 1

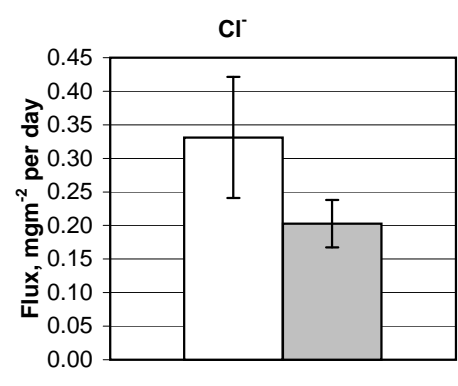

$\square$ April 22-27

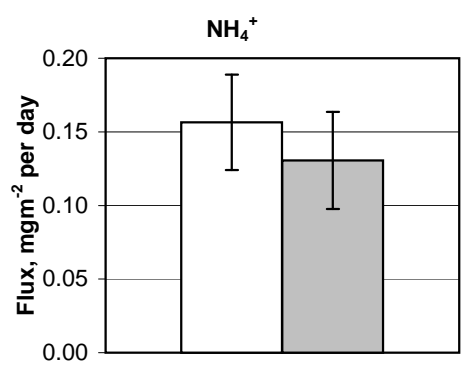

$\square$ April 22-27 $\square$ April 28 - May 1

Fig. 5. Average deposition fluxes with error bars of inorganic compounds and spheroidal particles of two sampling periods during the LAPBIAT measurement campaign, in $\# \mathrm{~m}^{-2}$ per day for spheroidal particles and $\mathrm{mg} \mathrm{m}^{-2}$ per day for other species. The fluxes are based on snow samples that were collected from several locations close to SMEAR I station.

range and over counted in over $\mu \mathrm{m}$ size range (Fig. 4). In fact APS model 3320 is not capable of reliably measuring aerosol concentration above $10 \mu \mathrm{m}$ due to recirculation of particles inside instrument (Stein et al., 2002). The used instruments, altogether, measured sizes from $0.4 \mathrm{~nm}$ to $20000 \mathrm{~nm}$. This is the widest size range measured so far at subarctic conditions.

\subsection{Coarse aerosol deposition by and to snow}

Total snow-sample-based deposition fluxes of major ions and spheroidal particles were clearly higher during the second sample period of 28 April-1 May than during the first period of 22-27 April (Table 3). Consequently, their diurnal deposition was the even much smaller for the first than for the second period (Fig. 5). The diurnal comparisons show that deposition of chloride $\left(\mathrm{Cl}^{-}\right)$is the only strong exception, while ammonium $\left(\mathrm{NH}_{4}^{+}\right)$does not show significant difference. Concentrations of sodium $\left(\mathrm{Na}^{+}\right)$and potassium $\left(\mathrm{K}^{+}\right)$ in the snow water were close to the detection limit in all snow samples.

Only one sample (No 5) represents the short intense snow accumulation period on 28-29 April. The sample shows that most of deposition (except $\mathrm{Ca}$ and spheroidal particles) during 28 April-1 May may have occurred already during the first day.

The deposition of large (presumably mineral) aerosol particles was calculated based on the coarse-particles mea- sured by EAS. According to the lower size limit of detecting the spheroidal particles in snow samples, the concentrations of aerosol particles in two and a half largest fractions of EAS spectra $(5-10 \mu \mathrm{m})$ were taken into account. In this size range, gravitation is the dominant deposition mechanism. The gravitational settling velocities were calculated from Stokes' law, assuming spherical shape of aerosol particles and density of $2800 \mathrm{~kg} \mathrm{~m}^{-3}$ for particulate matter. These selected properties are rather typical for mineral matter, e.g. silicate-rich fly ash.

The first snow sampling period (22-27 April) was from a period before the beginning of the campaign and the start of EAS measurements. We can only compare the later snow samples with the measured aerosol fluxes. The later snow sampling period was assumed to begin nearly at midnight right before 28 April, but EAS measurements are not available until early afternoon of the same day. Thus we used the average of the first $8 \mathrm{~h}$ as an approximation the aerosol particle size spectra for the previous night and forenoon hours, which count about $30 \%$ of the accumulation time of snow sample from site 5, 28-29 April sample, and for about 15\% for the other snow samples between 28 April-1 May. This way, we estimate the accumulated gravitational deposition from the EAS measurements was $7.5 \times 10^{6}$ aerosol particles during 28-29 April and $9.7 \times 10^{6}$ aerosol particles during 28 April-1 May. We estimated the mass deposition fluxes of 
Table 3. Results of snow-based deposition measurements from 6 locations (Site: No 1 at $67^{\circ} 45^{\prime} 04^{\prime \prime} \mathrm{N}, 2^{\circ} 35^{\prime} 36^{\prime \prime} \mathrm{E}$; No 2 at $67^{\circ} 45^{\prime} 9^{\prime \prime} \mathrm{N}$, $29^{\circ} 32^{\prime} 56^{\prime \prime} \mathrm{E}$; No 3 at $67^{\circ} 45^{\prime} 12^{\prime \prime} \mathrm{N}, 29^{\circ} 33^{\prime} 10^{\prime \prime} \mathrm{E}$; No 4 at $67^{\circ} 45^{\prime} 26^{\prime \prime} \mathrm{N}, 29^{\circ} 36^{\prime} 10^{\prime \prime} \mathrm{E}$; No 5 at $67^{\circ} 45^{\prime} 26^{\prime \prime} \mathrm{N}, 29^{\circ} 36^{\prime} 47^{\prime \prime} \mathrm{E}$; $\mathrm{No}^{6}$ at $\left.67^{\circ} 45^{\prime} 30^{\prime \prime} \mathrm{N}, 29^{\circ} 36^{\prime} 9^{\prime \prime} \mathrm{E}\right)$.

\begin{tabular}{|c|c|c|c|c|c|c|c|c|c|c|c|c|c|c|c|}
\hline & & & & & & & Cums & ative de & osition & $\mathrm{ng} \mathrm{m}^{-1}$ & & & & & \\
\hline $\begin{array}{l}\dot{0} \\
\stackrel{0}{\mathscr{Z}} \\
\dot{n}\end{array}$ & 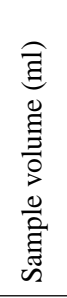 & 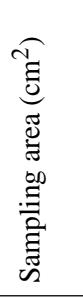 & 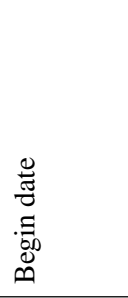 & 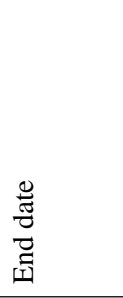 & 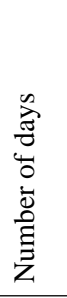 & 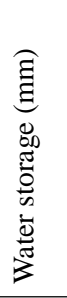 & $\mathrm{Cl}^{-}$ & $\mathrm{NO}_{3}^{-}$ & $\mathrm{SO}_{4}^{2-}$ & $\mathrm{Na}^{+}$ & $\mathrm{NH}^{4+}$ & $\mathrm{K}^{+}$ & $\mathrm{Ca}^{2+}$ & $\mathrm{Mg}^{2+}$ & 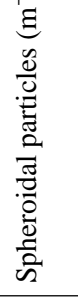 \\
\hline 1 & 335 & 1575 & 22 April & 27 April & 5.1 & 2.1 & 2.17 & 1.70 & 1.81 & - & 0.83 & 0.04 & 0.17 & 0.06 & 1159 \\
\hline 1 & 290 & 525 & 28 April & 1 May & 3.4 & 5.5 & 0.77 & 21.04 & 2.87 & 0.11 & 0.33 & - & 0.55 & - & 5794 \\
\hline 2 & 300 & 1575 & 22 April & 27 April & 5.2 & 1.9 & 1.98 & 1.01 & 1.85 & - & 0.86 & 0.02 & 0.13 & 0.08 & 2685 \\
\hline 2 & 280 & 525 & 28 April & 1 May & 3.4 & 5.3 & 0.59 & 17.48 & 2.45 & 0.05 & 0.48 & - & 1.12 & - & 6900 \\
\hline 3 & 240 & 1575 & 22 April & 27 April & 5.2 & 1.5 & 1.75 & 0.88 & 1.51 & - & 0.90 & 0.14 & 0.21 & 0.14 & 1839 \\
\hline 3 & 230 & 525 & 28 April & 1 May & 3.4 & 4.4 & 0.57 & 14.55 & 3.02 & 0.18 & 0.48 & 0.09 & 1.23 & 0.04 & 4211 \\
\hline 4 & 140 & 1575 & 22 April & 27 April & 5.3 & 0.9 & 0.99 & 0.94 & 0.84 & - & 0.53 & 0.11 & 0.41 & 0.09 & 529 \\
\hline 4 & 350 & 525 & 28 April & 1 May & 3.4 & 6.7 & 0.73 & 18.90 & 3.93 & 0.07 & 0.60 & - & 2.13 & - & 2513 \\
\hline 5 & 190 & 1575 & 22 April & 27 April & 5.4 & 1.2 & 1.76 & 1.98 & 1.41 & - & 0.98 & 0.05 & 0.25 & 0.16 & 2547 \\
\hline 5 & 190 & 525 & 28 April & 29 April & 1.7 & 3.6 & 0.51 & 20.84 & 2.71 & 0.14 & 0.33 & - & 0.69 & 0.14 & 3618 \\
\hline 5 & 310 & 525 & 28 April & 1 May & 3.5 & 5.9 & 0.89 & 17.52 & 2.95 & 0.24 & 0.30 & - & 1.30 & 0.12 & 6249 \\
\hline 6 & 320 & 525 & 28 April & 1 May & 3.4 & 6.1 & 0.61 & 17.28 & 4.14 & 0.06 & 0.49 & - & 3.96 & 0.12 & 8087 \\
\hline \multirow{2}{*}{\multicolumn{3}{|c|}{ Average }} & 22 April & 27 April & 5.2 & 1.5 & 1.73 & 1.30 & 1.48 & - & 0.82 & 0.07 & 0.24 & 0.10 & 1752 \\
\hline & & & 28 April & 1 May & 3.4 & 5.7 & 0.69 & 17.79 & 3.23 & 0.12 & 0.45 & 0.09 & 1.72 & 0.09 & 5626 \\
\hline \multirow{2}{*}{\multicolumn{3}{|c|}{$\begin{array}{l}\text { Standard } \\
\text { Deviation }\end{array}$}} & 22 April & 27 April & 0.1 & 0.5 & 0.45 & 0.50 & 0.41 & - & 0.17 & 0.05 & 0.11 & 0.04 & 916 \\
\hline & & & 28 April & 1 May & 0.0 & 0.8 & 0.13 & 2.13 & 0.66 & 0.07 & 0.11 & - & 1.21 & 0.04 & 1989 \\
\hline
\end{tabular}

aerosol particles from the same EAS data (Fig. 6) and obtained deposition values between 0 to $500 \mathrm{ng} \mathrm{m}^{-2} \mathrm{~s}^{-1}$. Our results show that the spheroidal particles constitute only a minor part (about $0.1 \%$ ) of total number concentration of aerosol particles in coarse fractions. This is expected, since even oil-shale fly ash, that is characterized by spheroidal particles, contains about $2 \times 10^{5}$ to $2 \times 10^{6}$ spheroidal particles per gram (Kaasik et al., 2005) which suggest that only $1 \%$ or less of aerosol particles are of this type.

\subsection{Particle formation events}

During the two-week campaign, three new aerosol particle formation events were observed. We will focus here on the event that we observed at SMEAR I station on 30 April, 2003. In the morning of that day, air masses arrived to Värriö from the Arctic Ocean. At noon the situation changed and while higher altitude (above $2000 \mathrm{~m}$ a.s.l.) air masses continued to arrive straight from the Arctic the lower level (below $1200 \mathrm{~m}$ a.s.l.) air masses passed deeper through the Kola Peninsula (Fig. 7).

The aerosol particle formation event begun at noon and was finished around 06:30 p.m. by a sudden appearance of larger aerosol particles in the size range of $20-200 \mathrm{~nm}$ as can be seen from aerosol particle size distributions measured with DMPS (Fig. 8) and EAS. This sudden change happened because of the change in the air mass demonstrated in Sect. 3.7. The difference in number concentration between aerosol particle size distribution measured by DMPS and number concentration measured by CPC TSI 3760 was largest between 09:00 to 12:00 a.m., which supports the suggestion that at that time there was aerosol particle formation and growth of smaller than the $14 \mathrm{~nm}$ diameter aerosol particles that can be observed with the aerosol particle number concentration measurements. Small aerosol particles were also observed from the ultrafine aerosol particle measurements made with the PHA-UCPC on from around 09:00 a.m. until 02:00 p.m., but not before or later (Fig. 3). The number concentrations from aerosol particle size distribution measured by DMPS and number concentration measurements by CPC TSI 3760 evened up at 06:15 p.m. At the same time around 06:30 p.m. the size distribution maximum moved to clearly towards larger-sized aerosol particles and there was a notable step up in the aerosol particle number concentration. 


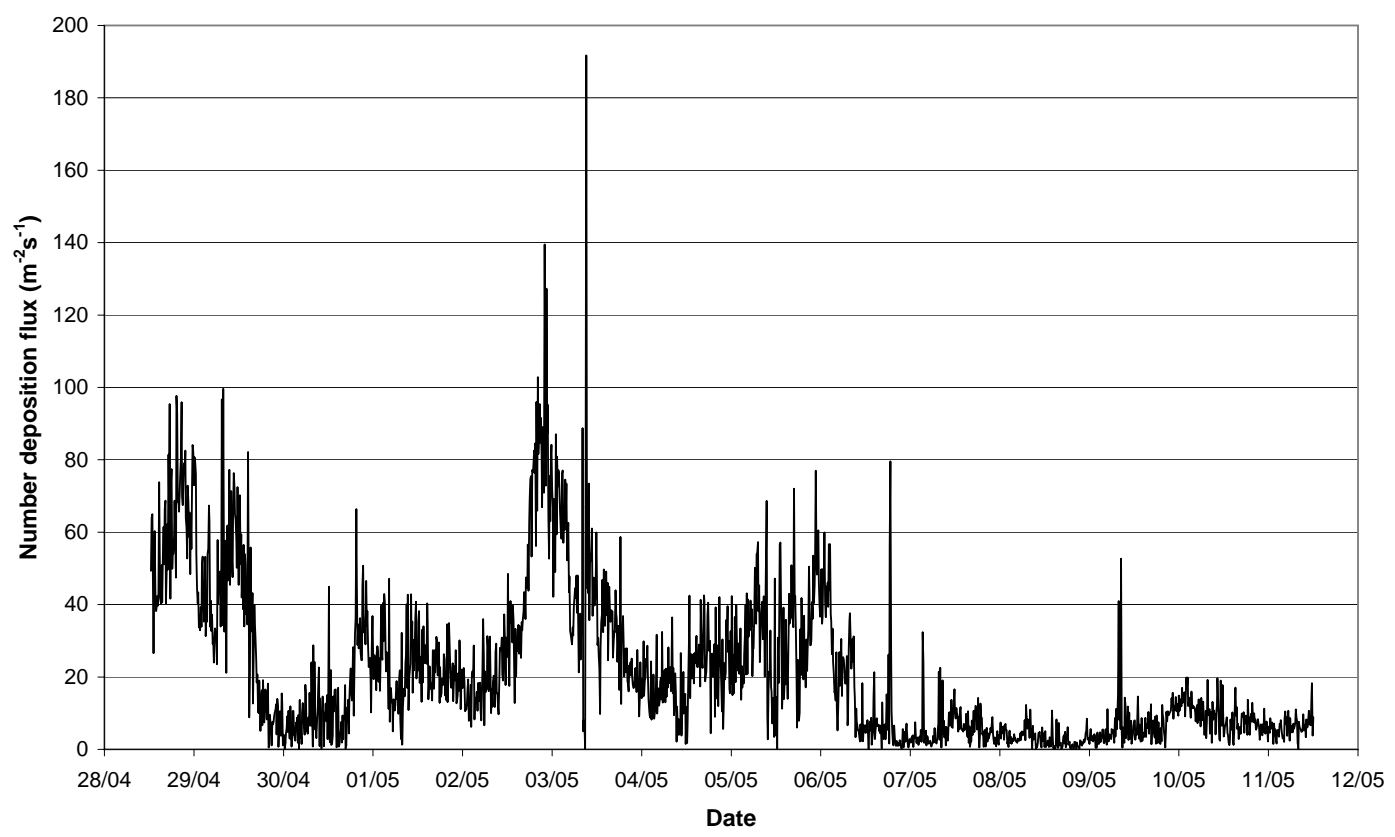

Fig. 6. Number deposition fluxes of coarse aerosol particles in size range 5-10 $\mu \mathrm{m}$, based on EAS measurements and gravitational settling assumption during the LAPBIAT measurement campaign at SMEAR I station.

(a)

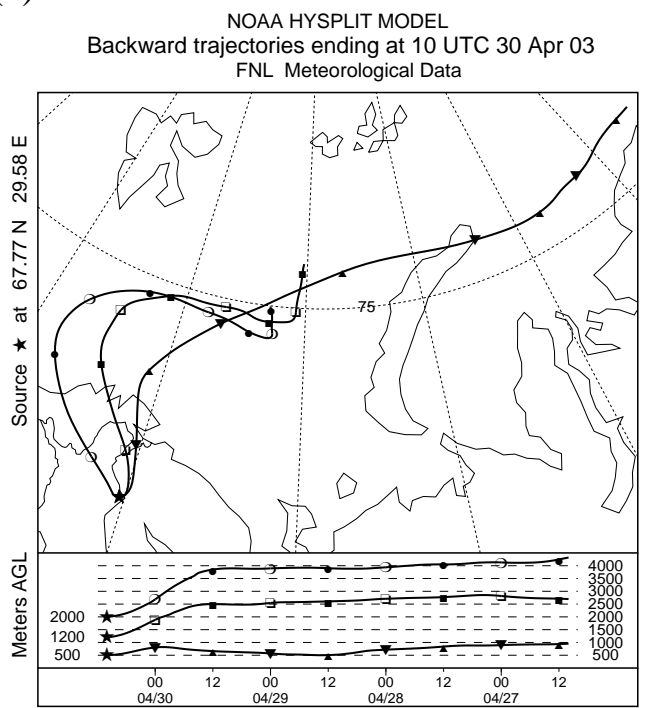

(b)

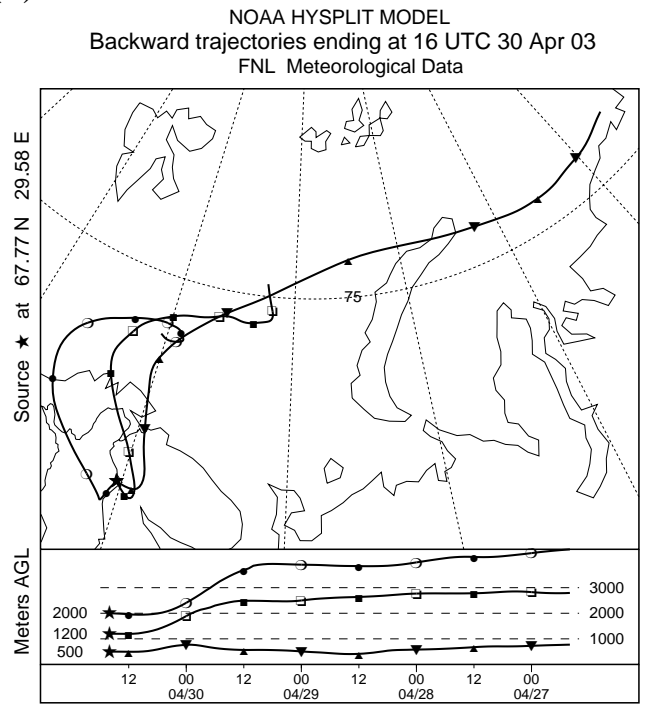

Fig. 7. Backward trajectories calculated using FNL data on the HYSPLIT4 model for 500, 1200 and 2000 m level at (a) 12:00 a.m. and (b) 06:00 p.m. for SMEAR I station (UTC+2 h), 30 April 2003.

The evolution of the charged fraction of aerosol particles, air ions in the size rage of $1.6-40 \mathrm{~nm}$ measured by AIS (Fig. 9), showed the same tendency as aerosol particles (Fig. 8). The generation of new particles followed by the intermediate ion (1.6-7.4 nm) measurements started at about 08:30 displaying the concentration maxima at 09:00 a.m. and 01:00 p.m. The concentration of negative light intermediate ions $(1.6-3.3 \mathrm{~nm})$ increases significantly during the nucle- ation burst, while the positive light intermediate ions stayed nearly at the same low background level. The concentrations of negative and positive intermediate ion in the size range of 3.3-7.4 nm were nearly equal. The excess of the negatively charged fraction is probably a robust indicator of the ion-induced nucleation on negative small (cluster) ions. The diurnal variation in the concentration of small (cluster) ions (diameter $0.46-1.6 \mathrm{~nm}$ ) displayed a slight maximum around 


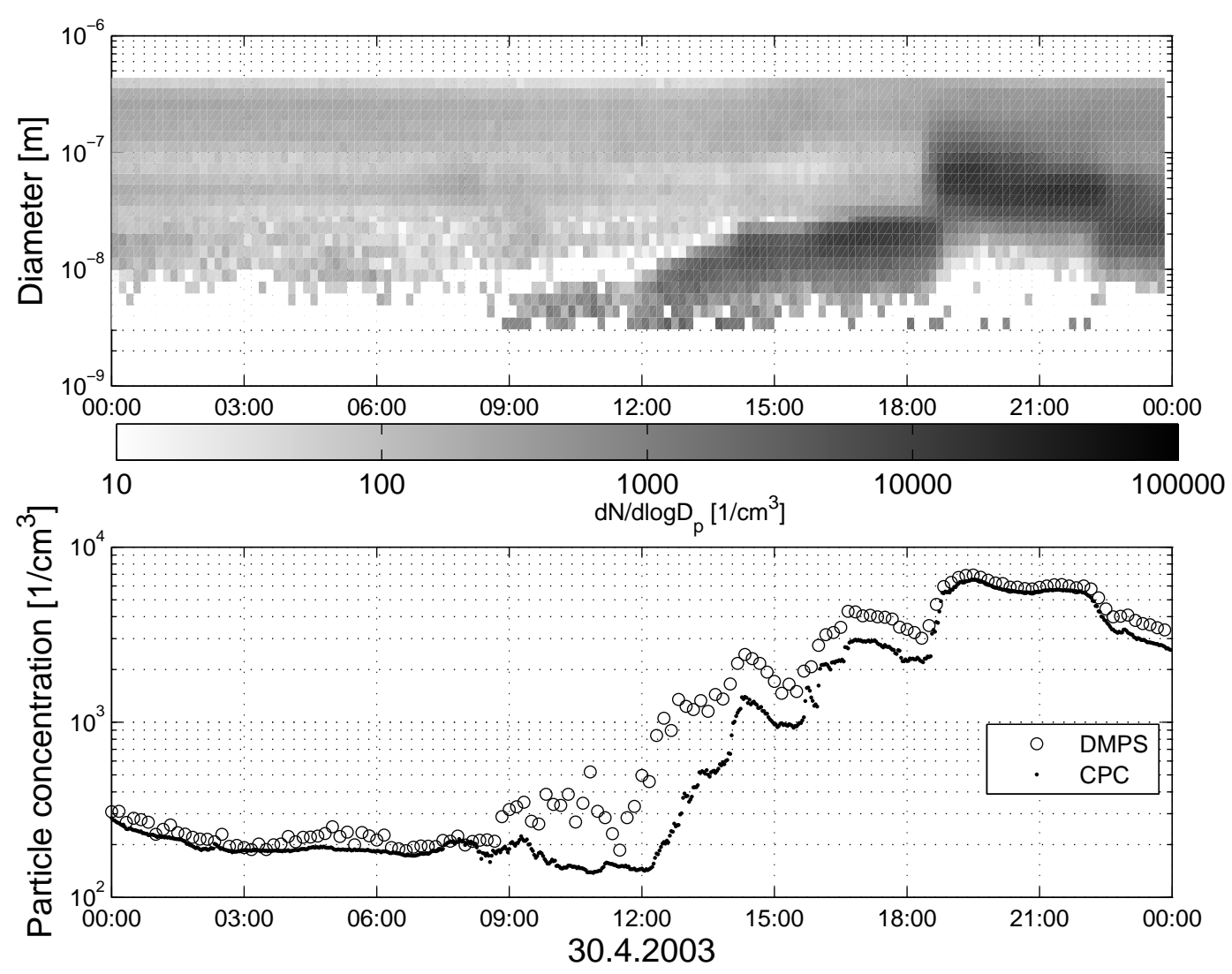

Fig. 8. Aerosol particle size distribution from DMPS measurements (a) and aerosol particle number concentrations from DMPS and CPC measurements (b) in SMEAR I station, 30 April 2003.

midday. A considerable decrease in the concentration of small ions as a result of the scavenging of small ions by aerosol particles followed after a sudden increase in the number concentration and the mean diameter of the aerosol particles at 06:30 p.m.

In Fig. 10 we present the growth rates as a function of size of aerosol particles measured by DMPS and charged aerosol particles (air ions) measured by AIS. We estimated the growth rates as temporal changes of diameter corresponding to the maximum number concentration in the measured size distribution. We fitted the data points with a polynomial of degree 3 that fits the data in a least square sense. The Fig. 10 shows the rather steep increase of growth rate with size at smaller diameters that levels out at diameter of about $10 \mathrm{~nm}$.

\subsection{Fine aerosol number fluxes}

The turbulent aerosol number flux is shown in Fig. 11 (positive is upward net fluxes, negative is downward fluxes or deposition). Many combined factors are needed in order to understand the changes between up and downward fluxes. Local emissions cannot be entirely excluded in order to explain the upward fluxes, but they can also be caused by non- stationary conditions when the eddy covariance method is not valid. What one must understand is that this is total aerosol number fluxes, dominated by the size range where both number concentrations and Brownian diffusion is the largest, at diameters $<100 \mathrm{~nm}$. Therefore, the coarse mode fluxes estimated and discussed in Sect. 3.4 have no connection to the measured fluxes. Periods of high concentrations of aerosol particles $<100 \mathrm{~nm}$ diameter are interesting, though as they can explain large deposition fluxes (for particle number concentration see Fig. 3). In Fig. 11 we can see several such periods, including the pollution episode like 3 May, and the aerosol formation events at 30 April, 5 May and 8 May. On all days when aerosol formation was observed, there were also large deposition fluxes, in agreement with previous observations. However, during pollution episode (3 May), $\mathrm{SO}_{2}$ concentration was high and aerosol flux pretty small. When there is aerosol formation, the aerosol number flux is downward indicating large deposition fluxes of small particles that recently formed above the surface layer/canopy (Nilsson et al., 2001). Considering example of the $24 \mathrm{~h}$ period from the midnight of 30 April to midnight of 1 May (Fig. 12), we see that the vertical aerosol flux is almost ideally zero until the aerosol formation event begins. After 12:00 a.m. the aerosol flux fluctuated strongly, but was mainly towards the 


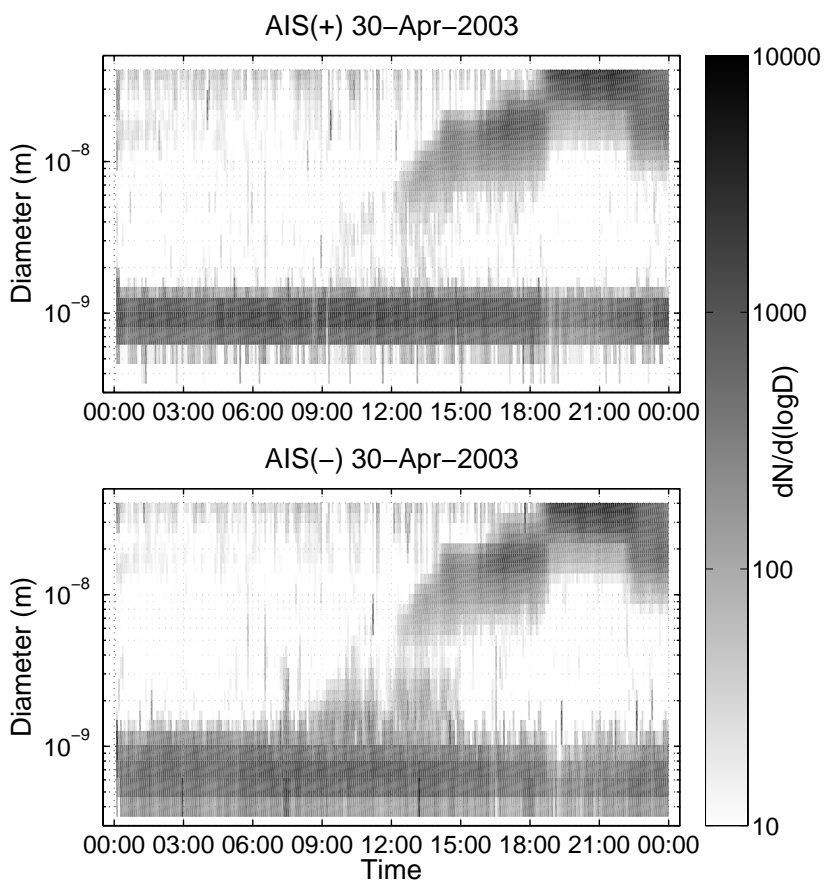

Fig. 9. Air ion size distribution from (AIS) for positive (upper panel) and negative air ions in SMEAR I station, 30 April 2003.

surface. Strongest downward flux appeared just at the moment of the outbreak of polluted air, but during the next hour the nearly-zero average flux was restored but strong fluctuations continued. The reoccurring variations in the vertical aerosol number flux may be due to presence of secondary circulations in the boundary layer, such as cloud streets (Buzorius et al., 2001). These circulations have a period near the 30 min averaging period of the flux calculations, which cause these fluctuations.

\subsection{Simulation of 30 April particle formation event}

The rapid change from clean to polluted air mass during 30 April was simulated with a Lagrangian particle model SILAM (Finnish Meteorological Institute), for a detailed description see Sofiev et al. (2005). The sulphate concentration in the air was used as an indicator of industrial pollution. EMEP data of industrial emissions from Central and Northern Europe, including Kola Peninsula were applied. We included $\mathrm{SO}_{2}$ emissions, and calculated its conversion into sulphate within the SILAM model. Model results (Fig. 13) show only marginal concentrations of $\mathrm{SO}_{4}^{-2}$ (below $0.1 \mathrm{ppb}$ ) during the nucleation event, but the $\mathrm{SO}_{4}^{-2}$ increases to the order of ppbs just after the breakdown of aerosol particle formation event. We also observed the same change in the measured concentrations of $\mathrm{SO}_{2}$ and $\mathrm{NO}_{\mathrm{x}}$. On 30 April, both measured concentrations were below the detection limit until they abruptly rose in the evening up to concentrations of over $4 \mathrm{ppb}$ of $\mathrm{SO}_{2}$ and $1 \mathrm{ppb}$ of $\mathrm{NO}_{\mathrm{x}}$ (Fig. 3).

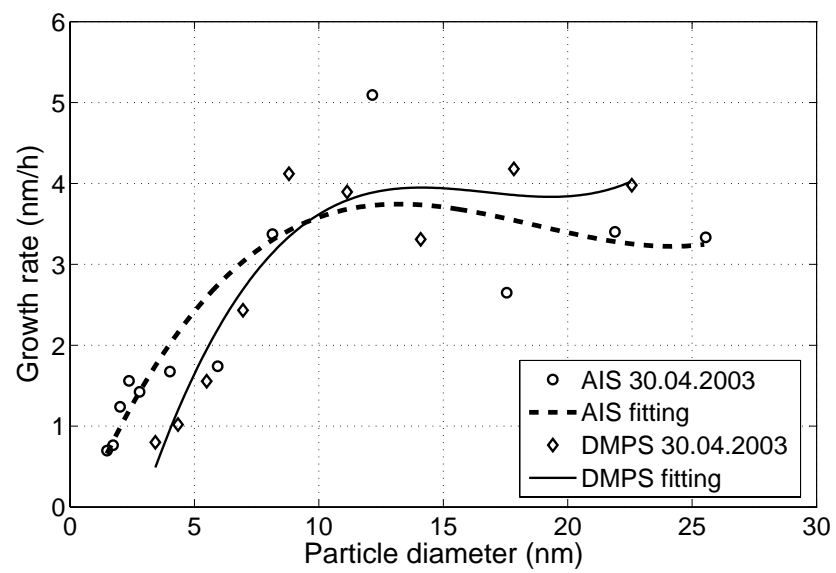

Fig. 10. The new particle and air ion growth rates as a function of size on 30 April 2003 at SMEAR I station.

3.8 Aerosol mass and size-segregated inorganic composition

A size-segregated aerosol mass concentration along with an unresolved mass is presented in Fig. 14. The first week of the campaign was generally clean with only a brief pollution outbreak. The second week was generally polluted bringing aged air masses from east and west. Accumulation and coarse modes are clearly revealed and there was little difference between two samples from aerosol mass point of view. The accumulation mode was centred around $0.4 \mu \mathrm{m}$ and the coarse mode mean diameter was around $2 \mu \mathrm{m}$. One can also see the upper shoulder of the Aitken mode, since the concentration of the first stage did not follow a decreasing pattern. However, the unresolved mass (difference between gravimetric mass and sum of analyzed inorganic species) showed significant difference between the samples, especially in the accumulation mode, where the unresolved mass was relatively small during the second week of the campaign. During the first week of the campaign there was large unresolved mass across all the sizes. Figure 15 presents the detailed contribution of each of inorganic species to the analyzed mass.

Most of the unresolved aerosol mass according to Fig. 14b can be attributed to organic matter, especially as long as the accumulation mode is concerned. Hence, organic matter contributed very significantly to the Aitken mode mass in both samples and the accumulation mode mass only in the first week sample. Figure 15a shows large contribution of sulphate to the Aitken mode mass and large contribution of ammonium to the accumulation mode. At the same time there was a very significant ion imbalance with a significant lack of positive ions in the Aitken mode and negative - in the accumulation mode. A significant lack of negative ions in the accumulation mode is thought to be due to not analyzed organic carbon species, e.g. organic acids or humiclike substances. Organic acid ions are likely contributing 


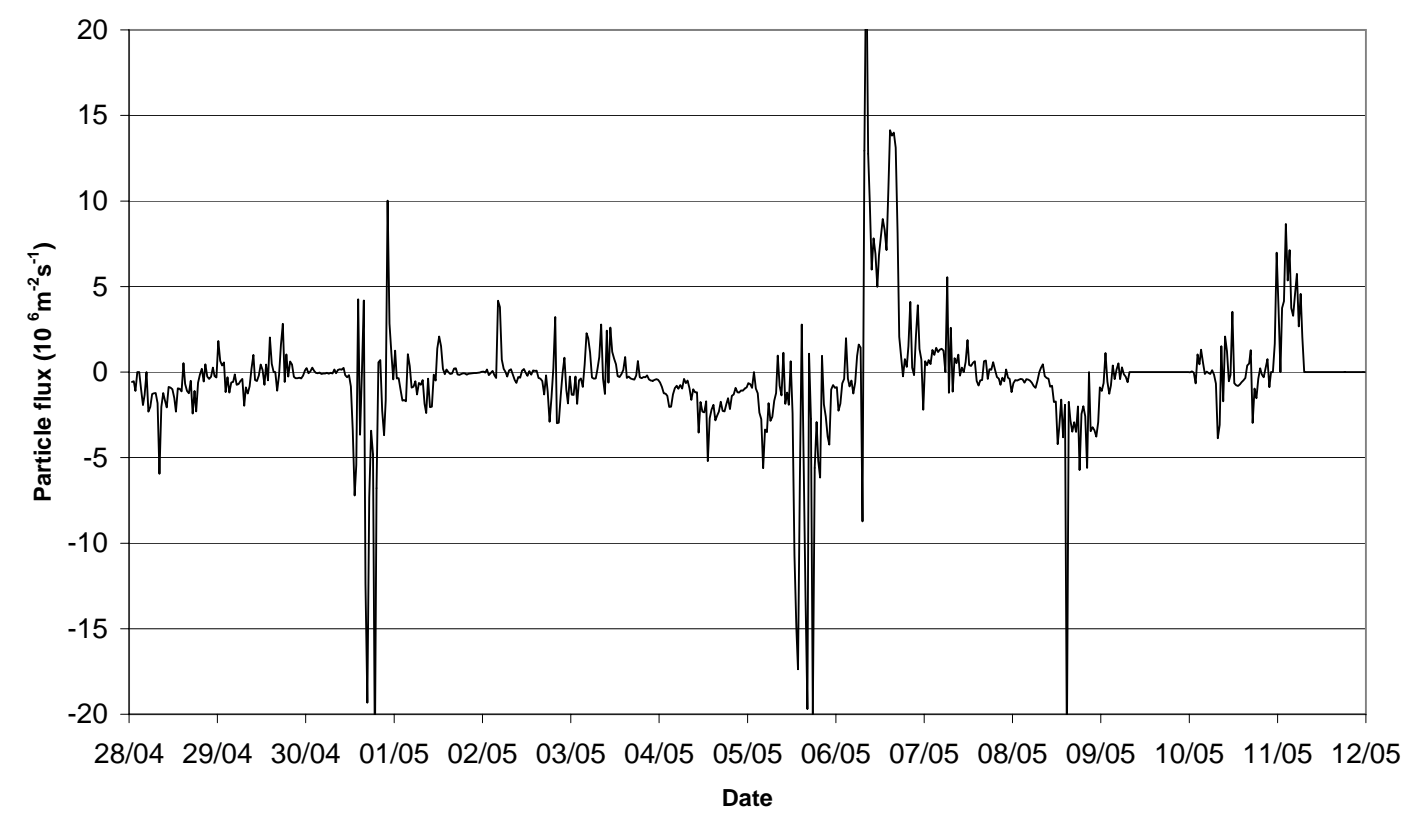

Fig. 11. Number deposition fluxes of aerosol particles measured by eddy covariance technique in SMEAR I station.

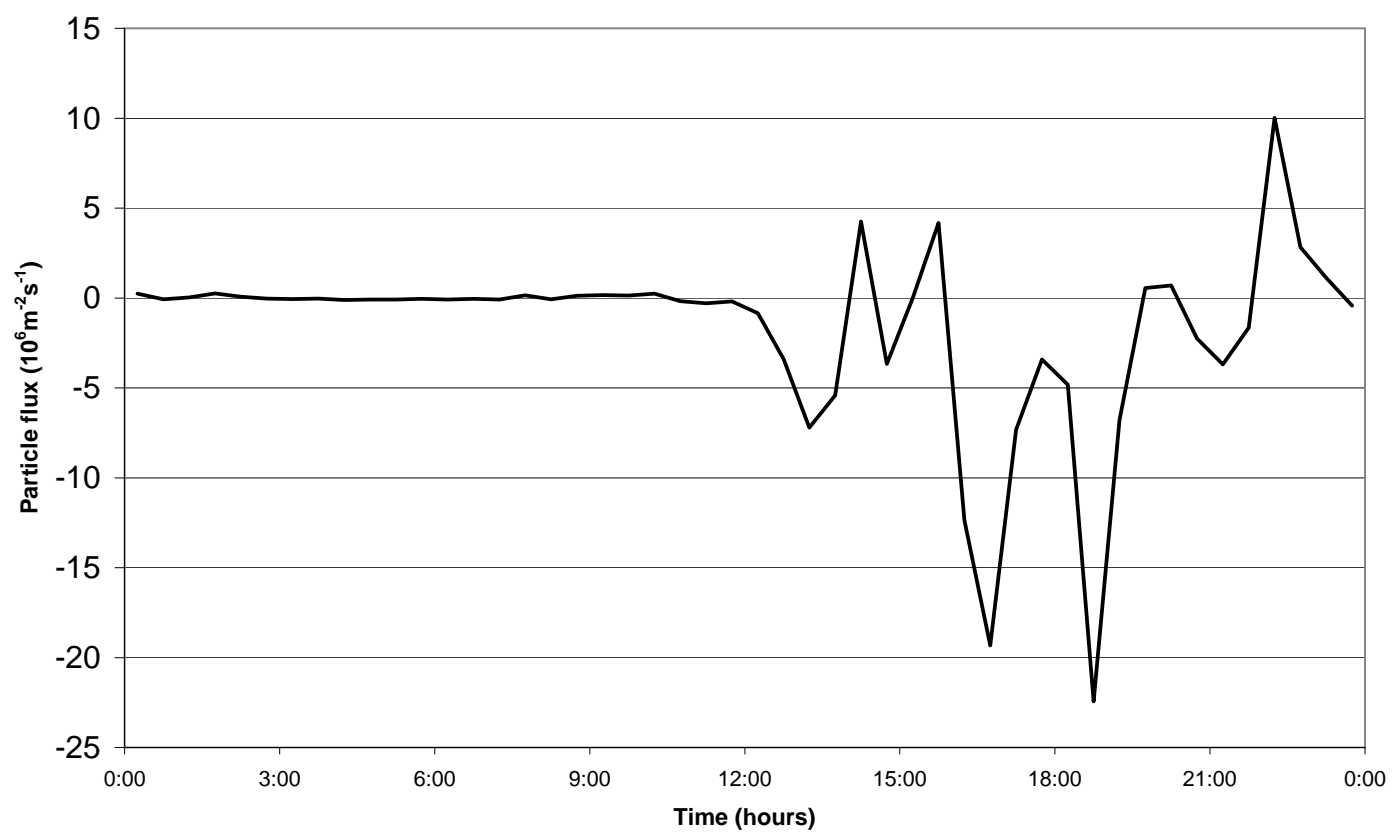

Fig. 12. Number deposition fluxes of aerosol particles measured using eddy covariance technique in SMEAR I station, closer view of 30 April.

to lacking negative ions and owing to their large molecular mass to significantly unresolved particulate mass in the first week sample. Another common anion not measured in this study is carbonate, but it is not quite common in accumulation mode and considering its relatively low molecular mass not quite capable of balancing the mass. In the aged polluted second week sample the ion balance was generally uniform across all the sizes with sulphate and ammonium dominating the accumulation mode. Owing to significant differences in concentration, mode and ion balance it is likely that the first week sample was a mixture of nucleation process and pollution outbreak. Therefore, it is likely that nucleation events involved sulphuric acid and organics, while during pollution outbreak the accumulation mode was only enriched in 
(a)

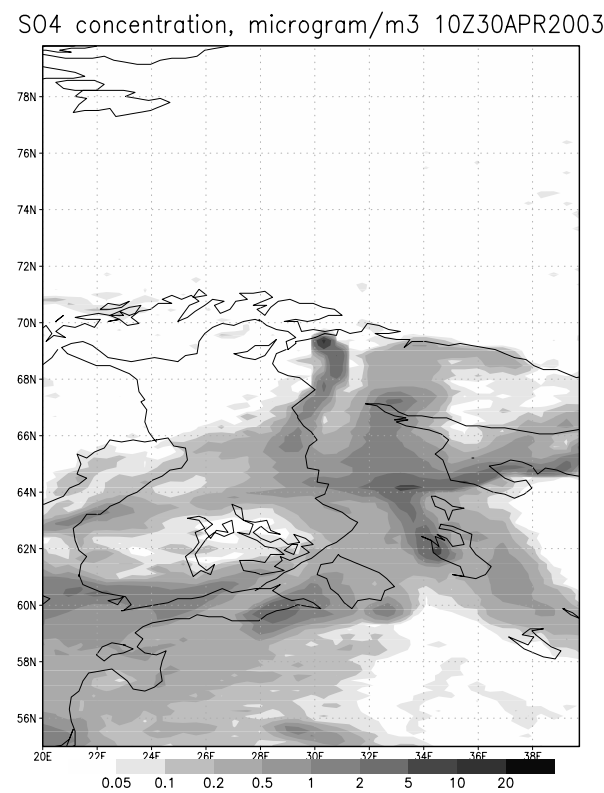

(b)

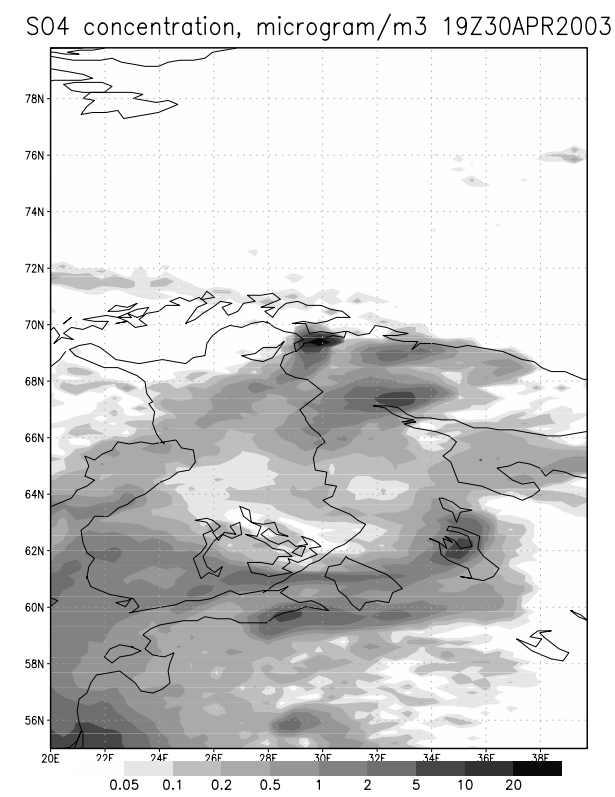

Fig. 13. SILAM model results for concentrations of sulphate ion in the air on 30 April: (a) average for 10:30-13:30 local time, in beginning of an observed aerosol formation event; (b) average for 19:30-22:30, shortly after the formation event was interrupted.

ammonium, but not sulphate, thus confirming that pollution source was likely not very distant, only as far as Kola peninsula. However, coarse size resolution of MOUDI impactor and lack of analyzed organics does not allow firm conclusions. It is becoming obvious that a high resolution aerosol mass spectrometer capable of high resolution aerosol mass and chemical measurements is needed to advance a link between chemical composition and atmospheric processes.

\section{Discussion}

\subsection{Coarse aerosol deposition}

Looking at the aerosol particle deposition (snow-based deposition measurements) data (Table 3, Fig. 5), it is obvious that the air was much cleaner, regarding mineral matter and main anthropogenic pollutants, before 28 April than afterwards. The only exception, chloride, is in agreement with the assumption of clean Arctic air mass: $\mathrm{Cl}$ in the snow samples probably originated from the seawater droplets blown up from the open Arctic Ocean a few hundred kilometres to north and northwest from the SMEAR I station. Also, results from the SILAM model as well as the $\mathrm{SO}_{2}$ and $\mathrm{NO}_{\mathrm{x}}$ measurements support these concepts.

Extremely large difference between the sample periods in deposition fluxes of nitrate seem to be related to the outbreak of more polluted air mass together with the snowfall. On the other hand, the deposition fluxes based on the sample of 28
29 April suggest that nearly entire deposition of most species during 28 April to 1 May occurred in first one and a half days of that period. However, this is not the case for the fluxes of $\mathrm{Ca}$ and spheroidal particles (i.e. presumably mineral matter in coarse particles): nearly a half of these species deposited after the evening of 29 April, possibly simultaneously with the outbreak of polluted air from Kola Peninsula.

The coarse aerosol particle $(5-10 \mu \mathrm{m})$ number flux estimations based on the EAS measurements (Fig. 6) result in total mass deposition of $25 \mathrm{mg} \mathrm{m}^{-2}$ for 28-29 April and $32 \mathrm{mg} \mathrm{m}^{-2}$ for a longer time 28 April-1 May. On the other hand, estimations based on snow samples (Table 3 ) suggest deposition of about $25 \mathrm{mg} \mathrm{m}^{-2}$ for 28-29 April and nearly zero for the rest of the longer time, i.e. 30 April-1 May. This is in fair agreement regarding the numerous assumptions made in the aerosol particle flux estimations based on the EAS measurements, limited statistics and probably noncomprehensive set of analysed chemical species. Both estimations of aerosol particle flux indicated that major part of the aerosol particle mass was deposited at 28 April and morning of 29 April. Then an outbreak of clean air mass followed, enabling the nucleation event at 30 April. Despite the notable number concentration of the newly formed particles, their mass concentration remained negligible. In the evening of 30 April and the following night some aerosol particle mass deposition occurred again from the industrially polluted air. 


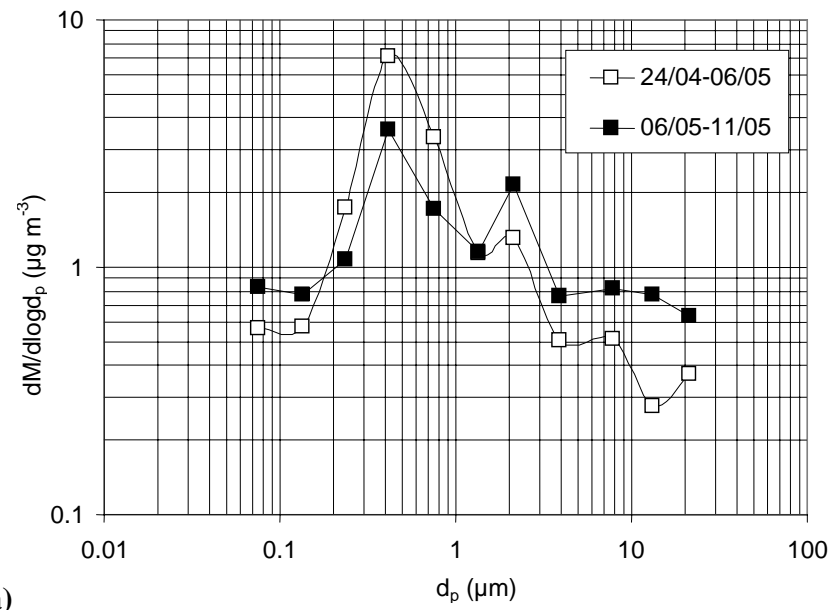

(a)

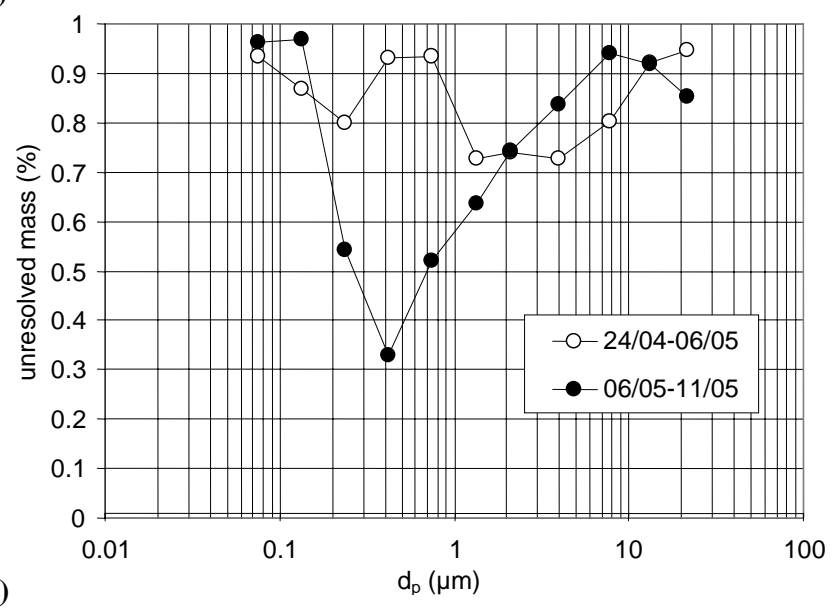

(b)

$d_{p}(\mu \mathrm{m})$

Fig. 14. (a) Size-segregated mass distribution and (b) unresolved mass (gravimetric mass - sum of inorganics) determined from MOUDI samples in SMEAR I station.

It is possible that nitrates and sulphates originated from the aged pollution in the form of fine aerosol, scavenged at the cloud level and washed out during the snowfall. A remarkable part of $\mathrm{Ca}$ (coupled with carbonate or other ions that were not analysed) and aerosol particles may have been carried by the air mass from industrial areas of Kola and dry deposited on the snow cover, as there was no snowfall during the aerosol pollution event at 30 April. From our estimations that the wind velocity at $500 \mathrm{~m}$ height was about $10 \mathrm{~m} \mathrm{~s}^{-1}$ and velocity of gravitational fall for $5-10 \mu \mathrm{m} \mathrm{min-}$ eral aerosol particles was in order of $5 \mathrm{~mm} \mathrm{~s}^{-1}$, we noticed that this diameter aerosol particles descended about $0.5 \mathrm{~mm}$ per meter of passing air, equalling to only $70-100 \mathrm{~m}$ during the atmospheric transport from Monchegorsk or Nikel. Thus, as stack height plus initial rise of buoyant plume for large industrial releases is typically a few hundreds of meters, spheroidal particles from these sources can easily reach Värriö and in dry weather a certain part of them pass well over that distance. However, cloud condensation processes can dramatically change the transportation distance.

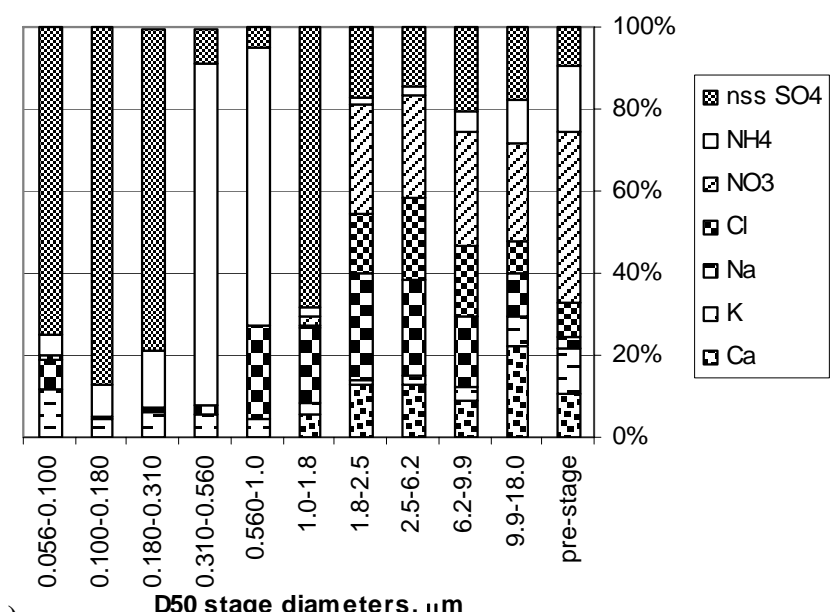

(a)

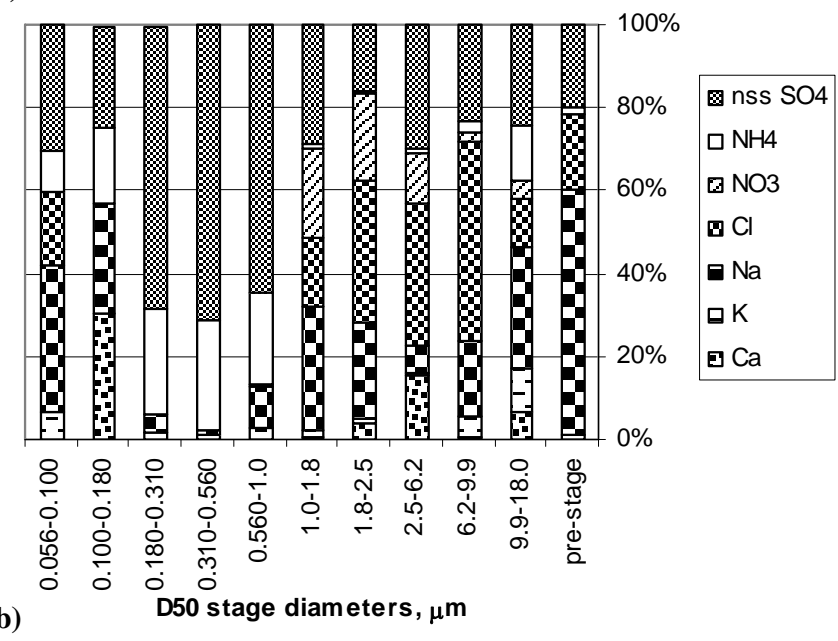

Fig. 15. Size-segregated aerosol inorganic composition as mass fractions determined from MOUDI samples in SMEAR I station (a) 24 April-6 May 2003 and (b) 6-11 May 2003.

Snow-based deposition measurements have been earlier successfully used to measure deposition loads, distinguish different periods of deposition and validate the air quality models in the conditions of Northern Europe (Kaasik et al., 2000; Sofiev et al., 2003). However, this is the first time they were coupled with extensive aerosol particle measurements. The results from this campaign suggest that coordinated aerosol and deposition measurements open new possibilities for interpreting the results.

\subsection{Fine mode aerosol fluxes and formation}

Our campaign results are consistent with the previous observation that aerosol particle formation and growth events occur typically during clear sky conditions (Vehkamäki et al., 2004). Prior the formation event the condensation sink decreased, the same has been observed by Vehkamäki et al. (2004), in about half of formation events observed in 
Värriö. This was explained by Nilsson et al. (2001) as dilution caused by entrainment of clean air from above the mixed layer.

Higher ozone concentrations have also been observed during event days, which could be explained by photochemical reaction cycles (Seinfeld and Pandis, 1998). The same could explain the observed lower $\mathrm{NO}_{\mathrm{x}}$ concentrations. In addition, biogenic activity could be higher on sunny days and emissions of biogenic VOCs of e.g. monoterpenes could be higher and once oxidized these compounds may contribute to the aerosol particle growth (see also Tunved et al., 2006). These findings are similar to the recent observation made in Hyytiälä at SMEAR II station (Kulmala et al., 2004b; Lyubotseva et al., 2005).

The aerosol fluxes measured by eddy covariance method in the beginning of all three observed nucleation events (30 April, 5 May and 8 May) were downwards (clear peaks in Fig. 5), indicating that the main process of formation of new aerosol particles was going on above the canopy. This is in agreement with the conclusions of Nilsson et al. (2001) and Buzorius et al. (2001) for SMEAR II station observations in Hyytiälä.

The particle growth rates were estimated for the observed nucleation events, fitting the concentration maximums for AIS, DMPS and EAS spectral fractions as described by Hirsikko et al. (2005). The basic concept of two linear sections fitting to the maximums of different particle size intervals was found valid (Table 4). The event No 2, gives too high growth rate, in comparison with others, and this is associated with change of air masses. Otherwise the observed growth rates are in agreement with those described elsewhere (Kulmala et al., 2004a, 2005; Komppula et al., 2006).

\section{Summary and conclusions}

The LAPBIAT measurement campaign took place in the SMEAR I measurement station located in Eastern Lapland in the spring of 2003 between 26 April and 11 May. LAPBIAT (Lapland Atmosphere-Biosphere) facilitys' goal is to enhance the international scientific co-operation at the Finnish Arctic research stations involved in the program. In this paper we have described the measurement campaign, concentrations and fluxes of aerosol particles and air ions, paying special attention to an aerosol particle formation event broken by a polluted air mass approaching from industrial areas of Kola Peninsula, Russia. Besides this we have also reported trace gas concentrations and used snow samples to verify deposition processes.

The main aim of the study is to find out different features of new particle formation using various experimental methods. During the campaign three aerosol particle formation events were observed. The events were characterised measuring air ion and aerosol particles size distributions, sizesegregated aerosol composition, number and mass fluxes,
Table 4. Particle growth rates during observed nucleation events at SMEAR I station.

\begin{tabular}{lllll}
\hline Nucleation event & $\begin{array}{l}\text { Size interval } \\
\text { of particles (nm) }\end{array}$ & \multicolumn{3}{l}{ Growth rate $\left(\mathrm{nm} \mathrm{h}^{-1}\right)$} \\
& & AIS & DMPS & EAS \\
\hline \multirow{2}{*}{ Event 1 (30 April) } & $3-7$ & 2.0 & 2.2 & 1.7 \\
& $7-20$ & 3.3 & 3.7 & 3.3 \\
Event 2 (5 May) & $3-7$ & - & - & - \\
& $7-20$ & 15.6 & 13.0 & 14.2 \\
Event 3 (8 May) & $3-7$ & - & 1.5 & 1.8 \\
& $7-20$ & 1.4 & 1.3 & 1.4 \\
\hline
\end{tabular}

deposition to snow and trace gas concentrations. The new particle formation events are typically related to clean Arctic air. The cleaness of the air mass is seen from size distribution measurements and also from the results of sizesegregated impactor measurements and snow samples. In clean air masses the main component is sea salt, an in polluted air masses the concentration of other inorganic compounds were significantly larger.

During and just before events, the concentrations of preexisting aerosols, larger than nucleation mode sizes were at their lowest concentration. During the events the concentration of intermediate ions increased indicating that ions are particpating in new particle formation. However, their contribution is not dominating one. Correspondingly, the observed foramtion and growth rates are in agreement with values observed in other continental environments (see Kulmala et al., 2004a) and also the increase of the growth rate as a function of particle size was observed (see Hirsikko et al., 2005). The strong downward aerosol (number concentration) fluxes during all three observed nucleation events suggest that new aerosol particles are formed above the canopy and transported down into the canopy layer.

If the Arctic air mass changed its route (like in 30 April) and passed trough industrial area in Kola Peninsula, the trace gas and aerosol concentrations increased and the aerosol composition changed. Due to this strong anthropogenic influence the new particle formation was not possible in that air mass, and the formation event seen at the site was interrupted.

This event was a good proof of dramatic influence of high pre-existing aerosol concentrations to the new particle formation and their subsequent growth by condensation (condensation growth). The rapid increase of pre-existing aerosol concentration prevents further aerosol formation. Another proof was found in low aerosol concentrations before nucleation events. Both of those findings support recent theoretical findings (e.g. Kerminen and Kulmala, 2002; Kulmala et al., 2006). 
Snow sampling is shown to be a fruitful additional measure to aerosol size distribution measurements. Chemical and microscopic analyses of snow provide valuable information on the pollution of air mass at the coarse end of the aerosol particle spectrum. Reciprocal verification of measurements from air and from snow is possible and enhances the reliability of both measurements. Transport modelling based on atmospheric dynamics is also a useful tool for aerosol research, indicating the precise locations of aerosol sources. Closer coupling of atmospheric and aerosol models is suggested for the future.

Acknowledgements. This work was supported by Nordic Centre of Excellence BACCI, by the EU-project LAPBIAT, by the Swedish Research Council and by the Estonian Science Foundation, grants no. 4622, 5387 and 5002. Authors would like to thank D. Jasineviciene in Institute of Physics, Lithuania for inorganic analysis of MOUDI samples. The authors gratefully acknowledge the NOAA Air Resources Laboratory (ARL) for the provision of the HYSPLIT transport and dispersion model used in this publication.

Edited by: R. Cohen

\section{References}

Alliksaar, T., Hörstedt, P., and Renberg, I.: Characteristic fly-ash particles from oil-shale combustion found in lake sediments, Water, Air, Soil Pollut., 104, 149-160, 1998.

Bonn, B. and Mootgard, G. K.: Sesquiterpene Ozonolysis: Origin of Atmospheric New Particle Formation from Biogenic Hydrocarbons, Geophys. Res. Lett., 30(11), 1585, doi:10.1027/2003GL017000, 2003.

Boy, M. and Kulmala, M.: Nucleation Events in the Continental Boundary Layer: Influences of Physical and Meteorological Parameters, Atmos. Chem. Phys., 2, 1-16, 2002,

http://www.atmos-chem-phys.net/2/1/2002/.

Buzorius, G., Rannik, Ü., Nilsson, D., and Kulmala, M.: Vertical Fluxes and micrometeorology during aerosol particle formation events, Tellus B, 53, 394-405, 2001.

Charlson R. J. and Wigley, T. M. L.: Sulphate aerosol and climate change, Scientific American, 207, 48-57, 1994.

Claeys M., Wu Wang, Ion, A. C., Kourtchev, I., Gelencser, A., and Maenhaut, W.: Formation of secondary organic aerosols from isoprene and its gas-phase oxidation products through reaction with hydrogen peroxide, Atmos. Environ., 38(25), 4093-4098, 2004.

Clarke, A. D.: Atmospheric Nuclei in the remote free troposphere, J. Atmos. Chem., 14, 479-488, 1992.

Dal Maso, M., Kulmala, M., Riipinen, I., Wagner, R., Hussein, T, Aalto, P. P., and Lehtinen, K. E. J.: Formation and growth rates of fresh atmospheric aerosols: eight years of aerosol size distribution data from SMEAR II, Hyytiälä, Finland, Boreal Environ. Res., 10, 323-336, 2005.

Draxler, R. R. and Rolph, G. D.: HYSPLIT (HYbrid Single-Particle Lagrangian Integrated Trajectory) Model access via NOAA ARL READY Website (http://www.arl.noaa.gov/ready/hysplit4.html), NOAA Air Resources Laboratory, Silver Spring, MD, 2003.
Hakola, H., Tarvainen, V., Laurila, T., Hiltunen, V., Hellen, H., and Keronen, P.: Seasonal Variation of VOC Concentrations over a Boreal Forest, Atmos. Environ., 37(12), 1623-1634, 2003.

Hari, P., Kulmala, M., Pohja, T., Lahti, T., Siivola, E., Palva, L., Aalto, P., Hämeri, K., Vesala, T., Luoma, S., and Pulliainen, E.: Air pollution in Eastern Lapland: challenge for an environmental measurement station, Silva Fennica, 28, 29-39, 1994.

Hirsikko, A., Laakso, L., Hõrrak, U., Aalto, P. P., Kerminen, V. M., and Kulmala, M.: Annual and size dependent variations of growth rates and ion concentrations in boreal forest, Boreal Environ. Res., 10, 375-369, 2005.

Kaasik, M., Rõõm, R., Røyset, O., Vadset, M., Sõukand, Ü., Tõugu, K., and Kaasik, H.: Elemental and base anions deposition in the snow cover of north-eastern Estonia. The impact of industrial emissions, Water, Air, Soil Pollut., 121, 349-366, 2000.

Kaasik, M., Alliksaar, T., Ivask, J., and Loosaar, J.: Spheroidal fly ash particles from oil-shale-fired power plants in atmospheric precipitations. Possibilities of quantitative tracing, Oil Shale, 22, 547-562, 2005.

Kerminen, V.-M. and Wexler, A. S.: The occurrance of sulphuric acid-water nucleation in plumes: Urban Environment, Tellus B, 48, 65-82, 1996.

Kerminen, V.-M. and Kulmala, M.: Analytical formulae connecting the "real" and the "apparent" nucleation rate and the nuclei number concentration for atmospheric nucleation events, J. Aerosol Sci., 33, 609-622, 2002.

Komppula, M., Lihavainen, H., Hatakka, J., Paatero, J., Aalto, P., Kulmala, M., and Viisanen, Y.: Observations of new particle formation and size distributions at two different heights and surroundings in subarctic area in northern Finland, J. Geophys. Res., 108(D9), 4295, doi:10.1029/2002JD002939, 2003.

Komppula, M., Sihto, S.-L., Korhonen, H., Lihavainen, H., Kerminen, V.-M., Kulmala, M., and Viisanen, Y.: New particle formation in air mass transported between two measurement sites in Northern Finland, Atmos. Chem. Phys., 6, 2811-2824, 2006, http://www.atmos-chem-phys.net/6/2811/2006/.

Korhonen, P., Kulmala, M., Laaksonen, A., Viisanen, Y., McGraw, R., and Seinfeld, J. H.: Ternary nucleation of $\mathrm{H}_{2} \mathrm{SO}_{4}, \mathrm{NH}_{3}$, and $\mathrm{H}_{2} \mathrm{O}$ in the atmosphere, J. Geophys. Res., 104, 26349-26353, 1999.

Kourtchev, I., Ruuskanen, T., Maenhaut, W., Kulmala, M., and Claeys, M.: Observation of 2-methyltetrols and related photooxidation products of isoprene in boreal forest aerosols from Hyytiälä, Finland, Atmos. Chem. Phys., 5, 2761-2770, 2005, http://www.atmos-chem-phys.net/5/2761/2005/.

Kulmala, M., Toivonen, A., Mäkelä, J., and Laaksonen, A.: Analysis of Nucleation Mode Particles Observed in Boreal Forest, Tellus B, 50, 449-462, 1998.

Kulmala, M., Pirjola, L., and Mäkelä, J. M.: Stable Sulphate Clusters as a Source of New Atmospheric Particles, Nature, 404, 6669, 2000.

Kulmala, M., Hämeri, K., Aalto, P. P., Mäkelä, J. M., Pirjola, L., Nilsson, D. E., Buzorius, G,, Rannik, Ü., Dal Maso, M., Seidl, W., Hoffman, T., Janson, R., Hansson, H.-C., Viisanen, Y., Laaksonen, A., and O'Dowd, C. D.: Overview of the international project on biogenic aerosol formation in the boreal forest (BIOFOR), Tellus B, 53, 324-343, 2001.

Kulmala, M., Vehkamäki, H., Petäjä, T., Dal Maso, M., Lauri, A., Kerminen, V.-M., Birmili, W., and McMurry, P. H.: Formation 
and growth rates of ultrafine atmospheric particles: A review of observations, J. Aerosol Sci., 35, 143-176, 2004a.

Kulmala, M., Suni, T., Lehtinen, K. E. J., Dal Maso, M., Boy, M., Reissell, A., Rannik, Ü., Aalto, P., Keronen, P., Hakola, H., Bäck, J., Hoffmann, T., Vesala, T., and Hari, P.: A new feedback mechanism linking forests, aerosols, and climate, Atmos. Chem. Phys., 4, 557-562, 2004b.

Kulmala, M., Petäjä, T., Mönkkönen, P, Koponen, I. K., Dal Maso, M., Aalto, P. P., Lehtinen, K. E. J., and Kerminen, V.-M.: On the growth of nucleation mode particles: source rates of condensable vapour in polluted and clean environments, Atmos. Chem. Phys., 5, 409-416, 2005,

http://www.atmos-chem-phys.net/5/409/2005/.

Kulmala, M., Lehtinen, K. E. J., and Laaksonen, A.: Cluster activation theory as an explanation of the linear dependence between formation rate of $3 \mathrm{~nm}$ particles and sulphuric acid concentration, Atmos. Chem. Phys., 6, 787-793, 2006 a.

Kulmala, M., Reissell, A., Sipilä, M., Bonn, B., Ruuskanen, T. M., Lehtinen, K. E. J., Kerminen, V.-M., and Ström, J.: Deep convective clouds as aerosol production engines: Role of insoluble organics, J. Geophys. Res., 111, D17202, doi:10.1029/2005JD006963, 2006b.

Laakso, L., Anttila, T., Lehtinen, K. E. J., Aalto, P. P., Kulmala, M., Hõrrak, U., Paatero, J., Hanke, M., and Arnold, F.: Kinetic nucleation and ions in boreal forest particle formation events, Atmos. Chem. Phys., 4, 2353-2366, 2004a.

Laakso, L., Petäjä, T., Lehtinen, K. E. J., Kulmala, M., Paatero, J., Hõrrak, U., Tammet, H., and Joutsensaari, J.: Ion production rate in a boreal forest based on ion, particle and radiation measurements, Atmos. Chem. Phys., 4, 1933-1943, 2004 b.

Logan, J. A.: Tropospheric ozone: Seasonal behavior, trends and anthropogenic influence, J. Geophys. Res., 90, 10463-10482, 1985.

Lyubovtseva, Y. S., Sogacheva, L., Dal Maso, M., Bonn, B., Keronen, P., and Kulmala, M.: Seasonal variations of trace gases, meteorological parameters, and formation of aerosols in boreal forests, Boreal Environ. Res., 10, 493-510, 2005.

Marti, J. J., Weber, R. J., Saros, M. T., and McMurry, P. H.: Modification of the TSI 3025 condensation particle counter for pulse height analysis, Aerosol Sci. Technol., 25, 214-218, 1996.

Mordas, M., Kulmala, M., Petäjä, T., Aalto, P. P., Matulevičius, V., Grigoraitis, V., Ulevičius, V., Grauslys, V., Ukkonen, A., and Hämeri, K.: Design abd performance characteristics of a condensation particle counter UF-02proto, Boreal Environ. Res., 10, 543-552, 2005.

Mäkelä, J. M., Aalto, P., Jokinen, V., Pohja, T., Nissinen, A., Palmroth, S., Markkanen, T., Seitsonen, K., Lihavainen, H., and Kulmala, M.: Observations of ultrafine aerosol particle formation and growth in boreal forest, Geophys. Res. Lett., 24, 1219-1222, 1997.

Mäkelä, J. M., Dal Maso, M., Pirjola, L., Keronen, P., Laakso, L., Kulmala, M., and Laaksonen, A.: Characteristics of the Atmospheric Particle Fomation Events Observed at a Boreal Forest Site in Southern Finland, Boreal Environ. Res., 5, 299-313, 2000.

Mårtensson, E. M., Nilsson E. D., Buzorius G., and Johansson, C.: Eddy correlation measurements and parameterisation of particle emissions in an urban environment, Atmos. Chem. Phys., 769$785,2006$.
Nilsson, E. D., Rannik, Ü., Buzorius, G., Kulmala, M., and O'Dowd, C.: Effects of the continental boundary layer evolution, convection, turbulence and entrainment on aerosol formation, Tellus B, 53, 441-461, 2001.

O’Dowd, C. D., Hämeri, K., Mäkelä, J. M., Pirjola, L., Kulmala, M., Jennings, S. G., Berresheim, H., Hansson, H.-C., de Leeuw, G., Kunz, G. J., Allen, A. G., Hewitt, C. N., Jackson, A., Viisanen, Y., and Hoffmann, T.: A dedicated study of new particle formation and fate in the coastal environment (PARFORCE): overview of objectives and achievements, J. Geophys. Res., 107(D19), 8108, doi:10.1029/2001JD000555, 2002a.

O’Dowd, C., Aalto, P., Hämeri, K., Kulmala, M., and Hoffmann, T.: Atmospheric particles from organic vapours, Nature, 416, 4971798, 2002b.

O'Dowd, C. D., Aalto, P. P., Yoon, Y. J., and Hämeri, K.: The use of the pulse height analyser ultrafine condensation particle counter (PHA-UCPC) technique applied to sizing of nucleation mode particles of differing chemical composition, J. Aerosol Sci., 35, 205-216, 2004.

Pirjola, L., Laaksonen, A., Aalto, P., and Kulmala, M.: Sulphate Aerosol Formation in the Arctic Boundary Layer, J. Geophys. Res., 103, 8309-8322, 1998.

Ruuskanen, T. M., Reissell, A., Keronen, P., Aalto, P. P., Laakso, L., Grönholm, T., Hari, P., and Kulmala, M.: Atmospheric trace gas and aerosol particle concentration measurements in Eastern Lapland, Finland 1992-2001, Boreal Environ. Res., 8, 335-349, 2003.

Schröder, F. and Ström, J.: Aircraft Measurements of submicrometer particles $(>7 \mathrm{~nm})$ in the midlatitude free troposphere and tropopause region, Atmos. Res., 44, 333-356, 1997.

Seinfeld, J. H. and Pandis, S. N.: Atmospheric Chemistry and Physics, Wiley, N. Y., 1236-1237, 1998.

Sofiev, M., Siljamo, P., Valkama, I., Ivonen, M., and Kukkonen, J.: A dispersion modelling system SILAM and its evaluation against ETEX data, Atmos. Environ., 40, 674-685, 2005.

Sofiev, M., Kaasik, M., and Hongisto, M.: Distribution of alkaline particles over the Baltic Sea basin, Water, Air, Soil Pollut., 146, 211-223, 2003.

Sopauskiene, D. and Jasineviciene, D.: Changes in precipitation chemistry in Lithuania for 1981-2004, J. Environ. Monitoring, 8, 347-352, 2006.

Stein, S. W., Gabrio, B. J., Oberreit, D., Hairston, P., Myrdal, P.,B., and Beck, T. J.: An evaluation of mass-weighted size distribution measurements with the Model 3320 aerodynamic particle sizer, Aerosol Sci. Technol., 36, 845-854, 2002

Tunved, T., Hansson, H.-C., Kulmala, M., Aalto, P., Viisanen, Y., Karlsson, H., Kristensson, A., Swietlicki, E., Dal Maso, M., Ström, J., and Komppula, M.: One year boundary layer aerosol size distribution data from five Nordic background stations, Atmos. Chem. Phys., 3, 2183-2205, 2003,

http://www.atmos-chem-phys.net/3/2183/2003/.

Tunved, P., Hansson, H.-C., Kerminen, V.-M., Ström, J., Dal Maso, M., Lihavainen, H., Viisanen, Y., Aalto, P. P., Komppula, M., and Kulmala, M.: High natural aerosol loading over boreal forests. Science, 312, 261-263, 2006.

Vana, M., Kulmala, M., Dal Maso, M. Hõrrak, U., and Tamm, E.: Comparative study of nucleation mode aerosol particles and intermediate air ions formation events at three sites, J. Geophys. Res., 109, D17201, doi:10.1029/2003JD004413, 2004. 
Vehkamäki, H., Dal Maso, M., Hussein, T., Flanagan, R., Hyvärinen, A., Lauros, J., Merikanto, J., Mönkkönen, P., Pihlatie, M., Salminen, K., Sogacheva, L., Thum, T., Ruuskanen, T., Keronen, P., Aalto, P. P., Hari, P., Lehtinen, K. E. J., Rannik, Ü., and Kulmala, M.: Atmospheric Particle Formation Events At Värriö Measurement Station In Finnish Lapland 1998-2002, Atmos. Chem. Phys., 4, 2015-2023, 2004,

http://www.atmos-chem-phys.net/4/2015/2004/.
Virkkula, A., Hillamo, R. E., Kerminen, V.-M., and Stohl, A.: The influence of Kola Peninsula, continental European and marine sources on the number concentrations and scattering coefficients of the atmospheric aerosol in Finnish Lapland, Boreal Environ. Res., 2(4), 317-336, 1997. 